University of Wollongong

Research Online

Australian Institute for Innovative Materials -

Papers

Australian Institute for Innovative Materials

$1-1-2017$

\title{
RNA Biomarkers: Diagnostic and Prognostic Potentials and Recent Developments of Electrochemical Biosensors
}

\author{
Md Nazmul Islam \\ Griffith University \\ Mostafa Kamal Masud \\ University of Wollongong, mkm590@uowmail.edu.au \\ Md Hakimul Haque \\ Griffith University \\ Md. Shahriar Al Hossain \\ University of Wollongong, shahriar@uow.edu.au \\ Yusuke Yamauchi \\ University of Wollongong, National Institute for Materials Science, yusuke@uow.edu.au
}

See next page for additional authors

Follow this and additional works at: https://ro.uow.edu.au/aiimpapers

Part of the Engineering Commons, and the Physical Sciences and Mathematics Commons

Research Online is the open access institutional repository for the University of Wollongong. For further information contact the UOW Library: research-pubs@uow.edu.au 


\title{
RNA Biomarkers: Diagnostic and Prognostic Potentials and Recent Developments of Electrochemical Biosensors
}

\begin{abstract}
Ribonucleic acids (RNAs) are considered as effective and minimally invasive biomarkers for disease diagnosis and prognosis due to their critical role in the regulation of different cellular processes. Over the past several years, the rapid progress in RNA biomarker research has resulted in the development of a large number of high-performance RNA-detection methods. Most of these methods are based on molecular-biology techniques such as quantita-tive reverse transcription polymerase chain reaction (RTqPCR), microarrays, and RNA sequencing. In recent years, considerable attention has also been dedicated to developing RNA biosensors, exploiting micro- and nanofabrica-tion technologies, and various readout strategies, including electrochemical and optical transducers. Here, the recent developments of RNA biosensors are concisely reviewed with a special emphasis on electrochemical-detection approaches. The following points are also highlighted: i) all the types of clini-cally relevant RNAs (mRNAs, miRNAs, IncRNAs) and their diagnostic and prognostic potential in cancer are outlined, ii) major challenges associated with current techniques are identified, followed by a critical analysis of how these challenges have been addressed by different biosensing approaches, and iii) the current requirements that still need to be met for effective screening of RNA biomarkers in both research and clinical settings.
\end{abstract}

\section{Keywords}

developments, electrochemical, biosensors, diagnostic, rna, prognostic, biomarkers:, potentials, recent

\section{Disciplines}

Engineering | Physical Sciences and Mathematics

\section{Publication Details}

Islam, M., Masud, M. Kamal., Haque, M. Hakimul., Hossain, M. Al., Yamauchi, Y., Nguyen, N. \& Shiddiky, M. J. A. (2017). RNA Biomarkers: Diagnostic and Prognostic Potentials and Recent Developments of Electrochemical Biosensors. Small Methods, 1 (7), 1700131-1-1700131-20.

\section{Authors}

Md Nazmul Islam, Mostafa Kamal Masud, Md Hakimul Haque, Md. Shahriar Al Hossain, Yusuke Yamauchi, Nam-Trung Nguyen, and Muhammad J. A Shiddiky 


\title{
RNA Biomarkers: Diagnostic and Prognostic Potentials and Recent Developments of Electrochemical Biosensors
}

\author{
Md Nazmul Islam, Mostafa Kamal Masud, Md Hakimul Haque, \\ Md Shahriar Al Hossain, Yusuke Yamauchi, Nam-Trung Nguyen, \\ and Muhammad J. A. Shiddiky*
}

Ribonucleic acids (RNAs) are considered as effective and minimally invasive biomarkers for disease diagnosis and prognosis due to their critical role in the regulation of different cellular processes. Over the past several years, the rapid progress in RNA biomarker research has resulted in the development of a large number of high-performance RNA-detection methods. Most of these methods are based on molecular-biology techniques such as quantitative reverse transcription polymerase chain reaction (RT-qPCR), microarrays, and RNA sequencing. In recent years, considerable attention has also been dedicated to developing RNA biosensors, exploiting micro- and nanofabrication technologies, and various readout strategies, including electrochemical and optical transducers. Here, the recent developments of RNA biosensors are concisely reviewed with a special emphasis on electrochemical-detection approaches. The following points are also highlighted: i) all the types of clinically relevant RNAs (mRNAs, miRNAs, IncRNAs) and their diagnostic and prognostic potential in cancer are outlined, ii) major challenges associated with current techniques are identified, followed by a critical analysis of how these challenges have been addressed by different biosensing approaches, and iii) the current requirements that still need to be met for effective screening of RNA biomarkers in both research and clinical settings.

\section{Introduction}

Ribonucleic acid (RNA) biomarkers comprising different coding and noncoding transcriptome such as messenger RNA (mRNA), microRNA (miRNA), and long noncoding RNA (lncRNA) are becoming progressively crucial in understanding disease diagnosis and prognosis due to their recognized physiological role in gene expression and regulation. ${ }^{[1-9]}$ Dysregulation of these RNA biomarkers is involved in the initiation and progression of several diseases including cancers. ${ }^{[2,10-15]}$ Among the different types of RNAs, proteincoding RNAs are exclusively represented by mRNAs where aberrant mRNA expression could initiate cancer by altering the DNA methylation pattern and different cellular regulatory pathways such as chromatin modifications, cell adhesion, and cell cycles. ${ }^{[5,8]}$ A number of recent studies have reported a strong correlation between aberrantly expressed mRNA levels and various cancers including breast cancer, ${ }^{[16]}$

M. N. Islam, Dr. M. J. A. Shiddiky

School of Natural Sciences

Griffith University

Nathan Campus, QLD 4111, Australia

E-mail:m.shiddiky@griffith.edu.au

M. N. Islam, M. K. Masud, M. H. Haque, Prof. N.-T. Nguyen,

Dr. M. J. A. Shiddiky

Queensland Micro- and Nanotechnology Centre

Griffith University

Nathan Campus, QLD 4111, Australia

M. K. Masud, Dr. M. S. A. Hossain, Prof. Y. Yamauchi Institute for Superconducting and Electronic Materials

Australian Institute for Innovative Materials (AIIM)

University of Wollongong

Squires Way, Innovation Campus

North Wollongong NSW 2519, Australia

Prof. Y. Yamauchi

International Center for Materials Nanoarchitectonics (MANA)

National Institute for Materials Science (NIMS)

Ibaraki 305-0044, Japan

The ORCID identification number(s) for the author(s) of this article can be found under https://doi.org/10.1002/smtd.201700131.

DOI: 10.1002/smtd.201700131 lung cancer, ${ }^{[17]}$ malignant melanoma, ${ }^{[18]}$ and hepatocellular carcinoma. ${ }^{[19]}$ During mRNA biogenesis (i.e., transcription), mature mRNA is produced from pre-mRNA transcripts via a splicing process (i.e., introns removal from nascent RNA followed by the joining of exons). ${ }^{[20,21]}$ Any alterations in this splicing pattern, referred to as "alternative splicing", may trigger the production of miscellaneous mRNA isomers, which further generates diverse protein variants including oncoproteins. ${ }^{[2,21,22]}$ For example, alternatively spliced Fas mRNA isoform (exon 6 is missing) produces a soluble deregulatory protein known as sFas which triggers abnormal cell proliferation in cancer. ${ }^{[2,23]}$

These protein-coding mRNA genes represent only a small percentage of the total genome. On the contrary, more than $90 \%$ of the genomic DNA generates noncoding RNAs (ncRNAs), consisting of housekeeping (e.g., ribosomal RNA, transfer RNA) and regulatory noncoding RNAs (e.g., miRNA and lncRNA). ${ }^{[24]}$ In recent years, research focus has mostly been shifted toward discovery and translational studies of biomarkers based on miRNAs (19-25 bases) and lncRNAs (200 bases to 100 kilobases), due to their strong ability in regulating the gene 
expression. ${ }^{[4,10,25]}$ These RNAs do not take part in protein production (i.e., translation) but they actively regulate the post-transcriptional gene expression and remodeling of the epigenome (i.e., DNA methylation and histone modification). ${ }^{[26,27]}$ They are crucial for a range of controlled biological processes such as cell cycle regulation, pluripotency, retrotransposon silencing, etc. These controlled processes may be affected and eventually could contribute to cancer development when the sequences of noncoding RNAs have anomalies such as copy number variations, single nucleotide polymorphism, and mutations. ${ }^{[3,14]}$ For instance, it has been reported that dysregulated lncRNA, HOX transcript antisense RNA (HOTAIR), interacted with polycomb repressive complex 2 (PRC2) complex and actively involved in the progression of liver and breast cancer, ${ }^{[25]}$ whereas MALAT1 B7 lncRNA affected the RNA splicing functions and triggered several types of cancers such as breast, lung, uterus, pancreas, colon, prostate, and liver cancer. ${ }^{[25,28-30]}$

Until now, nucleic-acid-detection-based techniques such as quantitative reverse transcription polymerase chain reaction (RT-qPCR), ${ }^{[31,32]}$ microarrays, ${ }^{[33,34]}$ and RNA sequencing methods, ${ }^{[4,35]}$ have widely been applied for the effective analysis of RNA levels. These methods typically require some forms of amplification steps, cumbersome sample pretreatment procedure, and expensive instrumentation. Additionally, they often cannot amplify RNA sequences without a poly(A) tail due to the use of oligo(dT) primers for the amplification purpose. ${ }^{[36]}$ Additionally, relatively large sample volumes are required for sensing RNA biomarkers in body fluids to avoid sample heterogeneity, resulting from distinct physiological and systemic differences of clinical samples. ${ }^{[37}$ In this regard, a great deal of research has been carried out to find relatively robust, accurate, and effective methods, leading to several nanotechnology-based RNA sensing approaches coupled with optical and electrochemical readouts. These approaches offer relatively easy sampling procedures, rapid and cost-effective analysis, portability, label-free and amplification-free options. ${ }^{[38-42]}$ Among these methods, electrochemical methods have evidently achieved the ultrahigh sensitivity and selectivity with the high potential for multiplexed analysis in point-of-care platform. ${ }^{[40,43,44]}$ However, the functionality of electrochemical RNA sensors is still confined in the proof-of-concept studies and several challenges are yet to be addressed to transform the technologies into routine clinical applications. ${ }^{[37]}$

Here, we review the recent developments of RNA biosensing approaches, especially electrochemical approaches. The diagnostic and prognostic roles of RNA biomarkers are briefly discussed, followed by a specific discussion on current requirements that still need to be met for screening of RNA biomarkers in both research and clinical settings. We have also highlighted the major technical and biological challenges involved in the existing RNA detection strategies and provided suggestions for the future direction of the field.

\section{RNA Biogenesis}

The rate and extent of RNA biogenesis in the nucleus and their subsequent role in protein synthesis or gene regulation are subjected to several finely controlled pathways driven by various

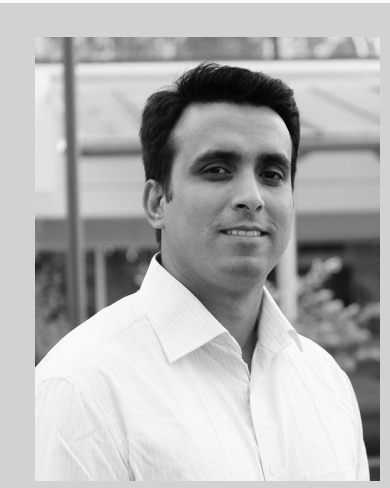

Md. Nazmul Islam is currently a Ph.D. student at the Shiddiky Research Laboratory, School of Natural Sciences, Griffith University, Australia. $\mathrm{His}$ research interest lies in the development of novel diagnostic technologies for detecting clinically relevant ribonucleic acids (RNAs). Prior to undertaking his Ph.D. study, he obtained his B.Sc. (Hons) and M.Sc. in biochemistry and molecular biology from the School of Biological Sciences, Jahangirnagar University, Bangladesh.

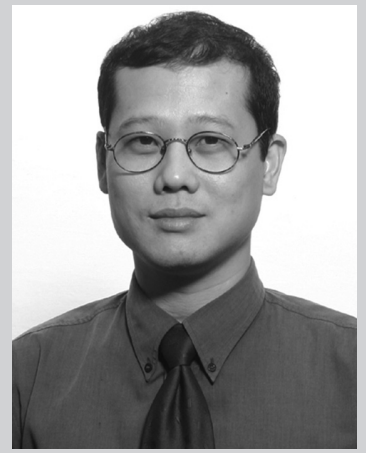

Nam-Trung Nguyen received his Dip-Ing, Dr Ing, and Dr Ing Habil degrees from Chemnitz University of Technology, Germany, in 1993, 1997, and 2004, respectively. From 1999 to 2012, he was an Associate Professor at Nanyang Technological University, Sigapore. From 2013, he has been a Professor and Director at Queensland Micro- and Nanotechnology Centre of Griffith University, Australia. His research is focused on microfluidics, nanofluidics, micro-/nanomachining, micro-/ nanoscale science, and instrumentation for biomedical applications.

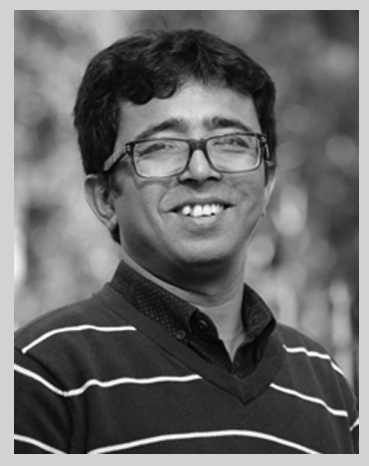

Muhammad J. A. Shiddiky graduated with a Ph.D. from Pusan National University, South Korea, in 2007. He is currently a Senior Lecturer and NHMRC CDF Fellow in the School of Natural Sciences at Griffith University. The primary goal of his research is to bring the next generation of microfluidics, electrochemistry, and nanobiotechnology tools to alleviate current problems in patient care, especially in cancer, infectious diseases, and neurodegenerative diseases. His group is working together with chemists, biomedical engineers, biologists, and clinicians for the development of novel nanomaterials, translational medicine technologies and devices for diagnosing, monitoring, and treating these diseases. 


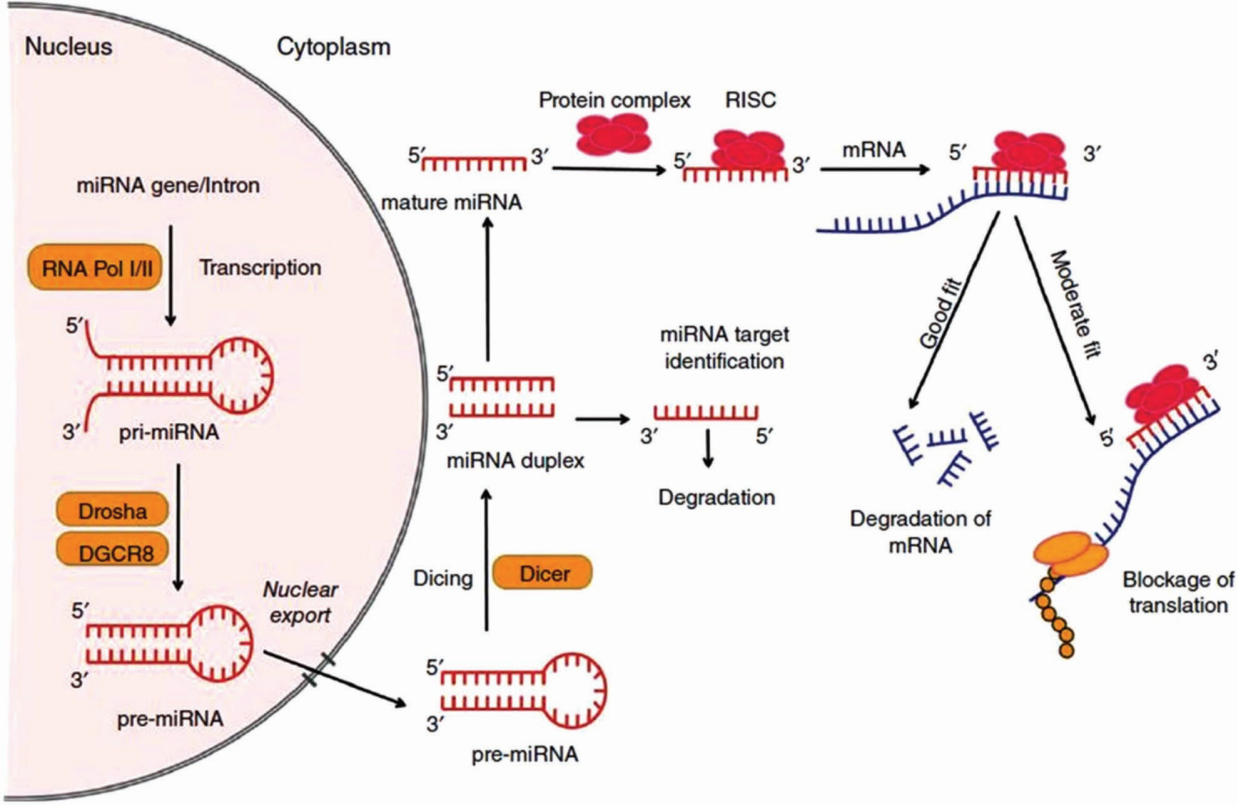

Figure 1. Schematic overview of miRNA biogenesis and regulation pathways. In the nucleus, miRNA genes are first transcribed to hairpin-structured pri-miRNA by RNA Pol. Next, microprocessor complex (Drosha and DGCR8) cleaves pri-miRNA to produce pre-miRNA, which is exported to the cytoplasm. In the cytoplasm, further cleavage by Dicer results in the formation of miRNA duplexes. Following strand separation of the duplexes, the mature miRNAs accumulate into RISCs to exert the regulatory function. Reproduced with permission. ${ }^{[3]}$ Copyright 2015, John Wiley and Sons.

cellular factors and enzymes. ${ }^{[45-47]}$ mRNA is synthesized in the nucleus from the DNA template of a target gene via a process known as "transcription." The transcription process is catalyzed by a large molecular enzyme referred to as RNA polymerase II (RNA Pol II). RNA Pol II recognizes and binds to the promoter site of the template DNA with the help of a group of proteins known as general transcription factors (GTFs). ${ }^{[48]}$ First, GTFs (e.g., TFIIA, TFIIB, TFIID, TFIIE, TFIIF, and TFIIH) assemble near the template DNA and assist RNA Pol II to recognize and bind the specific promoter region of the DNA thereby forming the preinitiation complex (PIC). The PIC then recruits DNA helicases, which facilitate DNA to expose their template strand for the initiation of RNA synthesis. After the initiation of transcription, the PIC leaves the template strand and RNA Pol II starts the elongation process and transcribes hundreds of kilobases of pre-mRNA transcripts. After that the RNA Pol II is dissociated from DNA template and started re-initiation of downstream transcription pathways. ${ }^{[45,46,49]}$ The resultant nascent pre-mRNA undertakes three major processing steps to form mature mRNAs, which usually occur co-transcriptionally (i.e., transcription and pre-mRNA processing happens simultaneously). These steps are $5^{\prime}$ capping, splicing and $3^{\prime}$ adenylation. ${ }^{[45,50]}$ Upon completion of the processing steps, mature mRNA is packaged inside a complex consisted of RNA binding proteins and other export factors. ${ }^{[45]}$ Then this complex is transported from the nucleus to cytoplasm through the nuclear pore complex which spans over the nuclear envelope (NPC) for further activities. ${ }^{[45]}$

Similarly, miRNAs are synthesized in the nucleus by the same transcriptional machinery of mRNA biogenesis. ${ }^{[51]}$ However, after their export into the cytoplasm, they skip the protein synthesis steps and keep a role in gene regulation. ${ }^{[37,52]}$ During
miRNA biogenesis (Figure 1), miRNA genes are first converted to hairpin-structured primary miRNA (pri-miRNA) by either RNA pol I or II via transcription process. Pri-miRNAs are then cleaved and processed by a distinct protein complex known as the microprocessor complex, which consists of ribonuclease enzyme Drosha and RNA binding protein DGCR8 (also known as pasha). In the next step, the miRNAs are then exported to the cytoplasm and further cleaved by Dicer (an enzyme from RNase III family) to form miRNA duplexes. Following strand separation of the duplexes, mature miRNAs are produced, which start to accumulate various proteins and enzymes to form RNAinduced silencing complex (RISC). miRNA exerts its inhibitory and regulatory action via RISC-induced RNA degradation and post-translational inhibition. ${ }^{[52]}$ Although many aspects of the lncRNA biogenesis pathways are relatively less understood, it has been reported that the key processes involved in most of the recently discovered lncRNAs follow the common mRNA biogenesis pathway. ${ }^{[51,53]}$ However, a few other alternative pathways for the biogenesis of lncRNAs have been described, which employ another type of polymerase enzyme known as RNA pol III at the gene promoters and do not undergo a polyadenylation processing step. ${ }^{[51,54]}$

\section{Diagnostic and Prognostic Roles of RNA}

RNAs are the key regulators of gene expression network and involved in controlling cell-cycle, cell proliferation, differentiation, apoptosis, metabolism, and post-transcriptional pathways. $^{[2-6,8]}$ Dysregulated RNAs can affect one or several of these cellular pathways, resulting in tumor initiation and progression. Thus, they can be used in diagnosis, prognosis, and 
therapy monitoring of cancers. ${ }^{[5,55,56]}$ Although the specificity and reproducibility of circulating miRNA biomarkers is a subject to recent contradictory discussion (see Section 3.3), they offer several distinct advantages such as early detection, high stability, and ability to work as liquid biopsy for minimally invasive monitoring of cancer.

Early Detection: A number of studies have confirmed that RNA biomarkers have important clinical implications as the early indicator of cancer. ${ }^{[17,18,57-62]}$ This is mostly due to the fact that during the early development of tumor cells, they release significant amounts of RNA into the blood circulation and mostly being upregulated. For example, miR-200 was reported as an effective biomarker for the early detection of ovarian cancer. ${ }^{[63]}$

High Stability of Circulating miRNAs: Compared to mRNAs and lncRNAs, miRNAs have significantly higher stability in a clinical sample and can show robust expression pattern. ${ }^{[3,37,55,62]}$ Several studies have shown that circulating miRNAs are resistant to the degradation by RNases and also unaffected in extreme condition such as freeze-thawing, long-term storage, high $\mathrm{pH}$, and temperature. This high stability can be explained by the fact that they are well protected inside the microvesicles such as exosomes and apoptotic bodies, or attached with RNAbinding proteins. ${ }^{[63-65]}$

Circulating Biomarker for Minimally Invasive Detection of Cancers: Current techniques for cancer diagnosis commonly require invasive tissue biopsy, which is not always clinically feasible and associated with pain. ${ }^{[66]}$ However, tumor-specific circulating RNAs (miRNAs) available in accessible biological fluids such as serum, plasma, urine, saliva could bypass the need of tissue biopsy. ${ }^{[3,57,67,68]}$ In 2010, Weber et al. ${ }^{[69]}$ assessed 12 different body fluids including urine, saliva, plasma, tears, breast milk, peritoneal fluid, pleural fluid, seminal fluid, amniotic fluid, bronchial lavage, cerebrospinal fluid, and colostrum and showed that miRNAs are present in these body fluids. This wide distribution of miRNA in most biological fluids makes them a promising circulating biomarker for less or noninvasive diagnosis and more personalized monitoring of diseases. ${ }^{[66]}$ The prominent features of using miRNAs as a circulating biomarker are that they are minimally painful, and allow clinicians to quickly assess disease development and response to therapeutics. ${ }^{[70]}$ For example, Debernardi et al.[71] showed a noninvasive profiling of cell-free miRNAs extracted from the urine of patients with pancreatic ductal adenocarcinoma and chronic pancreatitis can efficiently differentiate the early and late stage tumors.

\subsection{Diagnostic Roles}

Different types of cancers have distinctive signature of mRNA expression pattern. For example, Miura et al. ${ }^{[17]}$ demonstrated that the expression of human telomerase reverse transcriptase ( $h T E R T)$ mRNA and epidermal growth factor receptor (EGFR) mRNA were associated with lung cancer metastasis. In this study, real-time RT-PCR was used to measure the serum hTERT mRNA and EGFR mRNA levels from 112 patients with lung cancer and 80 normal individuals. The levels of the mRNAs were significantly interrelated with tumor size, number, metastasis, and recurrence in lung cancer which elucidated $h T E R T$ and EGFR mRNA's role as diagnostic biomarker for lung cancer. Several other mRNAs were reported as the diagnostic indicators of epithelial ovarian cancer (EOC) due to their specific expression patterns in EOC. For instance, p53, BCL-2, BAX mRNAs are downregulated in EOC while ASAP1 mRNA is overexpressed. ${ }^{[72,73]}$ A genome wide analyses of mRNA expression in 136 breast cancer patients performed via RNA sequencing (RNA-seq) also showed that a number of 32 mRNAs can sensitively act as the diagnostic biomarkers for breast cancer. ${ }^{[74]}$

Alternative splicing can also trigger the production of aberrant mRNA isomers leading to the progression of many diseases including cancer. ${ }^{[21]}$ This could happen due to the mutations in the components of splicing machineries. ${ }^{[11]}$ A number of tumorspecific alternative splicing events have been reportedly considered as the effective diagnostic markers and therapeutic targets in different cancers such as breast and lung cancer. ${ }^{[75,76]}$ Additionally, mRNA fusion, which is usually generated from gene fusion during aberrant chromosomal rearrangement events, have emerged as the new class of sensitive and specific diagnostic biomarkers for many cancers. For instance, TMPRSS2$E R G$ and $B C R-A B L$ mRNA fusions have been used as diagnostic markers for prostate cancer ${ }^{[59]}$ and leukemia, ${ }^{[77]}$ respectively.

In recent years, much attention has been dedicated to explore the diagnostic significance of miRNAs in cancer. ${ }^{[3,10,78]}$ In 2002, Calin et al. ${ }^{[79]}$ drew a relationship between cancer- and tissue-derived miRNA where it was demonstrated that miRNA cluster miR 15/16 was downexpressed in chronic lymphocytic leukemia. In a large cohort study, Volinia et al. ${ }^{[0]}$ screened 540 tumor samples derived from lung, breast, stomach, prostate, colon, and pancreas cancers, and identified 43 dysregulated miRNAs as diagnostic biomarkers. Later, in 2008, the diagnostic role of circulating miRNA in B-cell lymphoma was reported by Lawrie et al. ${ }^{[81]}$ This study reported that the levels of miR-21 and miR-155 were significantly higher in the serum sample derived from cancer patients compared to that of normal sample. Since then, an increasing number of cancer-related circulating miRNA have been identified and studied. ${ }^{[3,10,82]}$ For example, Zhou et al. ${ }^{[82]}$ showed the positive diagnostic potential of a group of circulating miRNAs (miR-122, miR-192, miR-21, miR-223, miR-26a, miR-27a, and miR-801) in a hepatocellular carcinoma (HCC) patient sample. In recent times, there is also an increasing interest on lncRNAs' research due to their wide biological functions and diagnostic potential. ${ }^{[12,25,60,83]}$ Among different lncRNAs, dysregulated HOTAIR is of great interest due to their robust expression pattern and active involvement in the prognosis, metastasis, and recurrence of a range of cancers. ${ }^{[13,25,60,83,84]}$ For example, Gupta et al. ${ }^{[84]}$ showed that the rate of HOTAIR transcription in metastatic breast cancer was almost 2000-fold raised compared to that of control. This significantly elevated levels of HOTAIR in cancer cells demonstrates their high diagnostic potential.

\subsection{Prognostic Roles}

Aberrant mRNAs have also been considered as a good indicator to predict and track tumor prognosis. In 2004, Spentzos et al. ${ }^{[85]}$ 
showed the positive prognostic behavior of a number of 115 mRNAs present in 68 patients with ovarian cancers where the mRNA profiling data successfully could predict the survival rate of patients. In another genome-wide approach, De Sousa et al. ${ }^{[86]}$ recruited 1100 patients with colorectal cancer where mRNA biomarkers successfully commented on the prognosis of colorectal cancer. In a few other related studies, aberrantly expressed NOTCH1 mRNA was found to be interrelated with poor survival of patients with non-Hodgkin lymphoma ${ }^{[87]}$ while Cyclin D1 and TS mRNA was linked with the poor survival of breast cancer patients. ${ }^{[16]}$

Compared to mRNA, miRNAs are more stable, ${ }^{[88]}$ which explains their good prognostic behavior in cancer. Over the past several years, a large number of miRNAs have been reported as effective indicators for the cancer prognosis. ${ }^{[89-91]}$ It was demonstrated that overexpressed miR-21 was significantly linked with the poor prognosis and therapeutic outcome of patients with colon cancer, ${ }^{[89]}$ while downregulated let-7 miRNA was correlated with poor survival of patients with lung cancer. ${ }^{[91]}$ In another study, the expression pattern of miR-335 and miR126 were lost when the condition of patients with breast cancer deteriorated, suggesting their active role in poor metastasis free survival (i.e., survival till the metastasis is detected). ${ }^{[92]}$ Apart from miRNAs, few of the recently discovered lncRNAs also showed fairly good prognostic behavior. ${ }^{[13]}$ For example, Kogo et al. ${ }^{[90]}$ studied the expression pattern of HOTAIR in 100 tissue samples collected from colon cancer and compared them with the matched normal sample where substantial changes in HOTAIR expression was observed. This study was extended to test samples derived from liver cancer where a strong correlation of upregulated HOTAIR with liver metastasis and poor disease prognosis were observed. In a similar approach, Liu et al. ${ }^{[93]}$ detected the overexpression of DANCR lncRNA in colorectal cancer tissues compared to that of matched normal tissues and their expression was highly correlated with the histologic grade and lymph node metastasis (Table 1 presents an overview of diagnostic and prognostic potentials of RNA biomarkers in various cancers).

\subsection{Contradictory Findings on Circulating miRNAs as a Biomarker: Critical Evaluation}

Despite recent advances in miRNA biomarker research, circulating miRNAs have not made the translation yet into the clinic, partly due to their contradictory specificity and inconsistent reproducibility issues as cancer biomarkers under different physiological and pathological conditions. ${ }^{[98-104]}$ For example, Haider et al. ${ }^{[98]}$ reviewed a total of 416 circulating miRNA biomarkers in 57 noncancerous diseases and identified that the differential expression of the miR-16, -155, -21, -126, and -223 biomarkers were not specific for any particular diseases, rather associated with at least 10 noncancerous conditions. Witwer et al. ${ }^{[99]}$ also published an extensive review on circulating miRNAs and showed the poor specificity and reproducibility of circulating miRNA as potential cancer biomarkers. In another study, Leidner et al. ${ }^{[103]}$ reviewed the irregular reproducibility of breast cancer related miR-21 and miR-155 biomarkers. Egidi et al. ${ }^{[100]}$ also pointed out the poor specificity issue of circulating
miRNA. They studied the expression level of miR-21 and miR141 in 38 prostate cancer patients after their radical prostatectomy (i.e., surgical removal of prostate gland) and showed that serum samples collected from patients with no prostate glands had significantly elevated level of miRNAs. This finding raised the concern as to whether elevated levels of miR-21 and miR141 in samples of prostate cancer patients collected after their radical prostatectomy is indicative of prostate cancer or simply related to general disease states such as inflammation.

Although, the miRNAs role as a cancer biomarker is under careful consideration, it is widely accepted that various biological and technical pitfalls associated with miRNA studies, including lack of automation and standard workflows in laboratories, inefficient sampling and extraction methods, and platform dependent variations could result in these inconsistencies. ${ }^{[37,101,102,105]}$ One possible solution for avoiding this variation is to directly screen miRNA that is released from the tumor rather than screening whole plasma or serum. This could be achieved by screening the extracellular vesicles (e.g., exosomes) derived miRNAs which have the capability of representing parental tumor cells. ${ }^{[99]}$

\section{Detection of RNAs: The Challenges}

Despite the recent development of RNA detection methodologies, several major challenges still remain. These challenges involve the following considerations.

\subsection{Stability of RNAs}

RNA is generally unstable at room temperature due to the chance of ribonucleases (RNase) associated degradation. Therefore, both endogenous and exogenous RNases can affect the accuracy of the detection via progressive degradation of the target RNA during incubation steps. One potential solution of this problem is the use of RNase inhibitor in the assay as demonstrated by Frei et al. ${ }^{[106]}$ In their multiplexed quantification assay for RNAs, referred to as PLAYR (proximity ligation assay for RNA), RNase inhibitor was used to avoid RNA degradation. This concern is not factual for RNAs available in various vesicles and biological molecules (e.g., exosomes and apoptotic bodies). The RNAs in these bodies are usually packaged into their structures (i.e., exosomal RNAs are protected by the membrane structure of exosome) and thus become inaccessible to RNases. ${ }^{[63-65]}$

\subsection{Sample Preparation and Choosing the Sample Source}

The efficiency of RNA detection is heavily influenced by the type of sample source and preparation method. ${ }^{[102]}$ Wang et al. ${ }^{[107]}$ showed that the expression level miRNA can be different in serum and plasma of the same individual. They found that miRNA concentrations in serum were higher compared to the corresponding plasma samples of the same person. They suggested that the presence of platelet-derived miRNAs originating from the blood coagulation process could be responsible for 
Table 1. RNA biomarkers associated with diagnosis and prognosis of cancer.

\begin{tabular}{|c|c|c|c|c|c|}
\hline Type of RNA & Target & Sample source and type & RNA expression & Diagnostic and/or prognostic RNA biomarkers & Ref. \\
\hline \multirow[t]{3}{*}{$\begin{array}{l}\text { Messenger } \\
\text { RNA (mRNA) }\end{array}$} & $\begin{array}{l}\text { hTERT mRNA, EGFR } \\
\text { mRNA }\end{array}$ & $\begin{array}{l}\text { Lung cancer tissue and serum with healthy } \\
\text { controls }\end{array}$ & Downregulated & $\begin{array}{l}\text { hTERT mRNA, combined with EGFR mRNA } \\
\text { as both diagnostic and prognostic biomarker } \\
\text { for pulmonary malignancies }\end{array}$ & [17] \\
\hline & ASAP1 mRNA & $\begin{array}{l}10 \text { pairs of epithelial ovarian cancer (EOC) tissue } \\
\text { and normal samples }\end{array}$ & Upregulated & $\begin{array}{l}\text { ASAP1 mRNA as prognostic marker of ovarian } \\
\text { cancer }\end{array}$ & [93] \\
\hline & cyclin D1 mRNA & $\begin{array}{l}\text { Tissue samples from } 151 \text { patients } \\
\text { with low-grade B-cell lymphoma }\end{array}$ & $\begin{array}{l}\text { Upregulated in } 128 \\
\text { patients }\end{array}$ & $\begin{array}{l}\text { Cyclin D1 mRNA as diagnostic marker } \\
\text { of Mantle cell lymphoma (MCL) }\end{array}$ & [94] \\
\hline Fusion mRNA & $\begin{array}{l}\text { TMPRSS2-ERG } \\
\text { mRNA }\end{array}$ & Transgenic mice prostate & Upregulated & Diagnostic marker of prostate cancer & [59] \\
\hline \multirow[t]{6}{*}{$\begin{array}{l}\text { microRNA } \\
\text { (miRNA) }\end{array}$} & $\begin{array}{l}\text { A number of } 470 \\
\text { human miRNAs } \\
\text { screened }\end{array}$ & $\begin{array}{c}76 \text { tumor and matched adjacent normal } \\
\text { tissues derived from radical prostatectomy } \\
\text { specimens }\end{array}$ & $\begin{array}{l}10 \text { upregulated and } 5 \\
\text { downregulated }\end{array}$ & $\begin{array}{l}\text { miR-96 as prognostic biomarker of prostate } \\
\text { cancer }\end{array}$ & [95] \\
\hline & $\begin{array}{l}\text { Global miRNA- micro- } \\
\text { array screening }\end{array}$ & $\begin{array}{l}\text { A number of } 123 \text { lung cancer } \\
\text { and matched normal tissues }\end{array}$ & $\begin{array}{l}35 \text { upregulated and } 3 \\
\text { downregulated }\end{array}$ & $\begin{array}{l}\text { Upregulated miR-21, miR-17-5p, miR-191, } \\
\text { miR-128b, miR-199a-1 as diagnostic bio- } \\
\text { markers for lung cancer }\end{array}$ & [80] \\
\hline & $\begin{array}{l}\text { Global miRNA- micro- } \\
\text { array screening }\end{array}$ & $\begin{array}{l}\text { Tissues derived from } 46 \text { colon cancer } \\
\text { and } 8 \text { normal individuals }\end{array}$ & $\begin{array}{l}21 \text { upregulated } \\
\text { and } 1 \text { downregulated }\end{array}$ & $\begin{array}{l}\text { Upregulated miR-21, miR-17-5p, miR-191, } \\
\text { miR-29b-2, miR-223, miR-128b, miR-24-1, } \\
\text { miR-24-2, miR-155, miR-20a, miR-107, miR-32, } \\
\text { miR-30c, miR-221, and miR-106a as positive } \\
\text { indicators of colon carcinoma }\end{array}$ & [80] \\
\hline & $\begin{array}{l}\text { A number of } 8 \\
\text { miRNAs screened }\end{array}$ & $\begin{array}{l}40 \text { prostate cancer tissue with } \\
\text { matched normal tissue samples }\end{array}$ & 2 downregulated & $\begin{array}{l}\text { Downregulated miR-205, miR-214 as } \\
\text { diagnostic marker for prostate cancer }\end{array}$ & [96] \\
\hline & $\begin{array}{l}\text { Global miRNA micro- } \\
\text { array screening }\end{array}$ & 79 breast cancer and 6 normal tissues & $\begin{array}{l}15 \text { upregulated and } 12 \\
\text { downregulated }\end{array}$ & $\begin{array}{l}\text { Upregulated miR-21, miR-17-5p, miR-29b-2, } \\
\text { miR-146, miR-155, miR-181b-1 as diagnostic } \\
\text { indicator of breast cancer }\end{array}$ & [80] \\
\hline & $\begin{array}{l}\text { Microarray for } \\
\text { screening total } 389 \\
\text { miRNAs }\end{array}$ & $\begin{array}{l}197 \text { primary colon tumor and } \\
\text { matched normal tissues }\end{array}$ & 37 miRNAs dysregulated & $\begin{array}{l}\text { Upregulated miR-21 linked with the poor sur- } \\
\text { vival of patients with colon adenocarcinoma }\end{array}$ & [89] \\
\hline $\begin{array}{l}\text { Long } \\
\text { noncoding }\end{array}$ & DANCR IncRNA & $\begin{array}{l}107 \text { colorectal cancer tissues with } \\
\text { paired adjacent normal tissues }\end{array}$ & upregulated & $\begin{array}{l}\text { Upregulated DANCR IncRNA as prognostic } \\
\text { marker for colorectal caner }\end{array}$ & [93] \\
\hline \multirow[t]{2}{*}{ RNA(IncRNA) } & HOTAIR IncRNA & $\begin{array}{l}100 \text { cancerous and matched } \\
\text { noncancerous tissues collected from patients with } \\
\text { colorectal cancer }\end{array}$ & upregulated & $\begin{array}{l}\text { Upregulated HOTAIR as prognostic marker for } \\
\text { colorectal cancer }\end{array}$ & [90] \\
\hline & HOTAIR IncRNA & $\begin{array}{l}\text { Serum collected from patients with esophageal } \\
\text { cancer (including } 42 \\
\text { tumor resection and } 8 \text { without surgery) } \\
\text { and } 20 \text { healthy volunteers }\end{array}$ & upregulated & $\begin{array}{l}\text { Upregulated HOTAIR as potential diagnostic } \\
\text { biomarker for esophageal cancer }\end{array}$ & [97] \\
\hline
\end{tabular}

this source-dependent variation. In another report, Leidinger et al. ${ }^{108]}$ showed that the influence of ethylenediaminetetraacetic acid (EDTA) on the expression and degradation of miRNA present in blood samples. EDTA has routinely been used as an anticoagulant in blood collection tubes for miRNA analysis in clinical settings. In this method, the sampling tubes were incubated with EDTA at different time intervals $(0 \mathrm{~min}$, $10 \mathrm{~min}$, and $2 \mathrm{~h}$ ) after the blood draw from 6 healthy individuals. It was observed that with increasing incubation time, the levels of miRNAs in the blood sample were significantly altered. The report suggested that transcription and degradation of the miRNAs in the white blood cells and platelets could still be dominating inside the sampling tube, causing a noticeable variation in the miRNA level derived from same individual under two different EDTA-incubation intervals. Therefore, the use of stabilizing reagents in the blood collection tubes is highly recommended to stop unexpected expression and degradation of miRNA (i.e., variations in miRNA expression level). ${ }^{[102]}$

\subsection{Low Sensitivity due to Ineffective Extraction Methods}

The readily available concentration of clinically relevant RNAs in tissues, serum, or other body fluids is very low. Therefore, a highly sensitive and specific method needs to be designed for extracting RNAs from body fluids. The RNA extraction method is also crucial because a little discrepancy in the analysis could result in false-positive responses. This observation was also evident from a study by McDonald et al.[109] who demonstrated that the majority of variance in the RNA detection was derived from the extraction process used. Thus choosing the right extraction method along with careful optimization 
(i.e., incubation time, centrifuging speed, etc.) of the extraction steps is necessary for obtaining accurate detection.

\subsection{Specificity Issues due to the Cross-Talk between RNAs}

RNAs originating from the same family often share similar physicochemical properties and sequences. ${ }^{[110]}$ Consequently, accurate and sensitive detection of RNAs is often compromised by the background response from the closely related sequences of nontarget RNAs. Over the past several years, many approaches have been employed to address this issue. For example, Castoldi et al. ${ }^{[111]}$ used a special type of thermostable probe known as locked nucleic acid in microarray assay to specifically detect single base mismatch and closely related miRNA sequences. In another study, Labib et al. ${ }^{[43]}$ used p19 protein (p19 exclusively binds with double stranded miRNA) in an electrochemical assay to reduce the background responses from closely related nontarget sequences.

\subsection{Nonspecific Response from Biomolecules}

The clinical sample may have complex biological environments containing various unknown cells and biomolecules such as proteins, which could nonspecifically be attached on the sensor surface resulting in false-positive responses. Therefore, a suitable blocking agent such as mercaptohexanol, mercaptoethanol, poly(ethylene glycol), or bovine serum albumin can be used to prevent nonspecific bindings. ${ }^{[112]}$

\subsection{Varying Size of RNAs}

The length of RNA spans over very small (e.g., miRNA, 18-20 nt) to large (e.g., lncRNA > 200 nt). Compared to longer RNAs, detection of short RNAs becomes challenging due to their size match with primers of amplification-based detection techniques. To address this issue, short RNAs can be enzymatically polyadenylated to produce longer sequences before the reverse transcription step in RT-qPCR via using oligo-dT primers. ${ }^{[13]}$ Another possible way to avoid primer match with target RNA is to use a stem-loop primer during reverse transcription, which formed a nicked RNA hybrid via hybridization with the $3^{\prime}$ end of the target RNA sequence. ${ }^{[114]}$ On the other hand, the detection of long RNAs using hybridization-based approaches also a significantly challenging task. This could be explained by the fact that, due to the presence of an extra free oxygen atom in the additional ribose of the RNA structure, long RNAs are prone to interaction between nucleotides and often obtain secondary and tertiary structure ${ }^{[115,116]}$ on the sensor surface, thereby minimizing the hybridization efficiency.

\subsection{Physiological Variation in Humans}

Natural variation in the expression levels of RNAs both between and within individuals is a considerable issue in RNA detection in clinical samples, which mostly could be the result of differences in gender, race, age, diet of individuals, etc. It has also been revealed that the variation is more when the sample size is small $(<100$ individuals), therefore the variation can be lessened by recruiting a large cohort of sample. ${ }^{[37]}$

\section{RNA Biomarker Detection Technologies}

\subsection{Amplification-Based Molecular-Biology Techniques}

Amplification-based nucleic acid detection methods such as RT-qPCR, microarrays, and RNA-seq have been widely used for RNA biomarker detection and expression analysis. In these methods, generally the RNA template is reverse transcribed to complementary DNA (cDNA) using an RT enzyme. RT is a RNA-dependent DNA polymerase enzyme that creates cDNA libraries from mRNA. cDNA is then further amplified by PCR or RNA-seq for detection purpose. ${ }^{[117,118]}$

\subsection{1. $R T-q P C R$}

RT-qPCR is a sensitive and widely used method for RNA analysis due to the advantages associated with the requirement of relatively less starting RNA, wide dynamic range, and better accuracy. ${ }^{[117]}$ Over the past several decades, a great number of RT-qPCR-based RNA expression analysis methods have been developed and also commonly used in clinical trials. ${ }^{[31,32,78,110,119]}$ In 2005, Chen et al. ${ }^{[114]}$ developed one of the well-known methods for miRNA analysis, referred to as TaqMan miRNA assay (Figure 2I). In this method, a unique stem-loop reverse transcriptase was adopted for cDNA conversion which was followed by TaqMan PCR analysis for the quantification of total 5 miRNAs present in mouse tissues. This method has since been extensively used to quantify miRNAs for different applications. The beautiful feature of this method is that it can differentiate closely related miRNA sequences having as low as one nucleotide difference. Mestdagh et al. ${ }^{[120]}$ described a systematic approach to compare the analytical performance of twelve commercially available miRNA analysis platforms including RT-qPCR, microarray and RNA-seq. Among these methods, the RT-qPCR offers the highest sensitivity for the analysis of miRNA. Although RT-qPCR is sensitive and efficient for measuring relative concentrations of RNA with respect to an internal standard, it has a limitation for the absolute quantification of RNAs. ${ }^{[102,120]}$ Another potential weakness of this method is that it usually works with a small number of expressed genes and, thus, is not suitable for high-throughput RNA screening. ${ }^{[117]}$ It is also important to note that this method is effective for already established and prevalidated RNA biomarkers while microarray and RNA-seq methods are well-suited for the discovery and validation of novel RNA biomarkers ${ }^{[102,121,122]}$

\subsubsection{Microarray-Based Methods}

Being a relatively less expensive method, microarray-based assays can simultaneously profile a large number of RNAs and offer multiplexed analysis. ${ }^{[33]}$ Typically a microarray comprises thousands of spots containing multiple oligonucleotides probes 

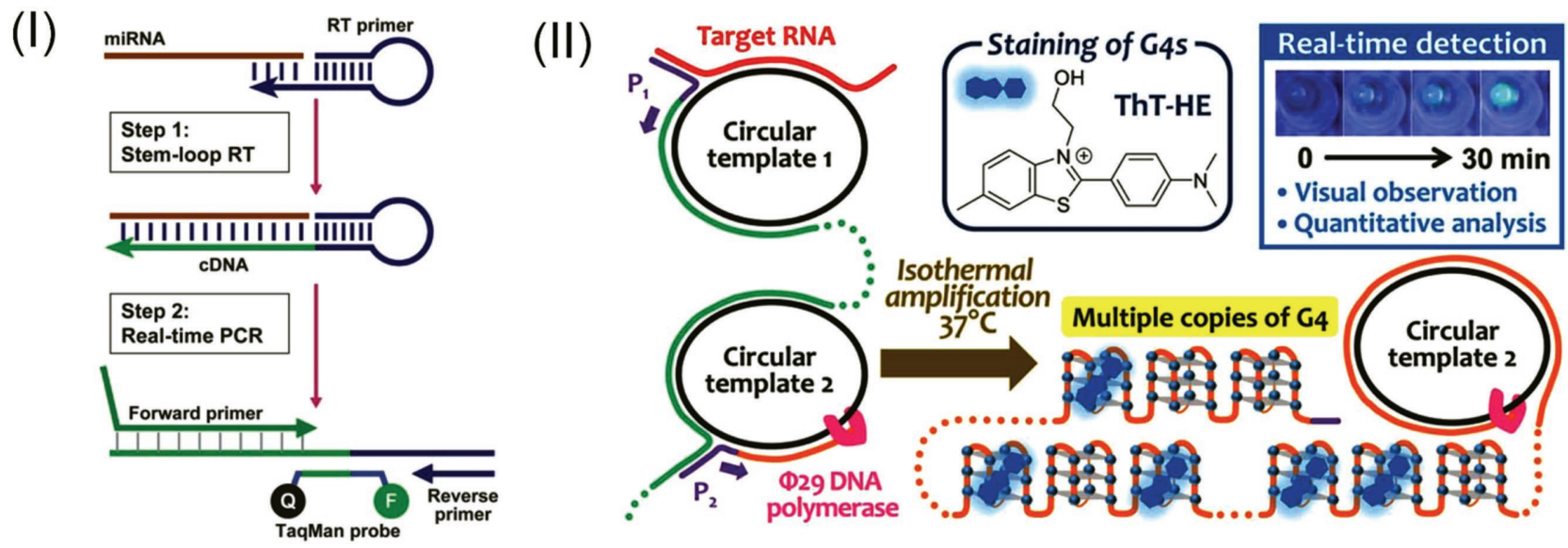

(III)

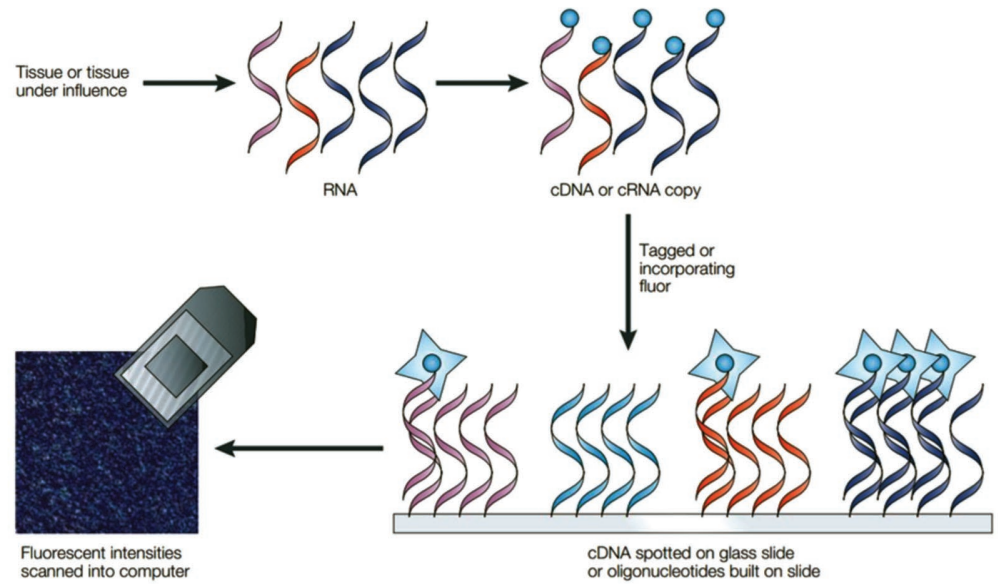

Figure 2. Amplification-based molecular-biology techniques for RNA biomarker detection. I) A schematic of the TaqMan PCR method for the analysis of miRNA. Stem-loop RT primers anneal at the $3^{\prime}$ site of the miRNA targets and reverse transcribed to produce cDNA. Then, miRNA-specific forward and reverse primer and a dye-labeled TaqMan probe are used to quantify the amplified miRNAs. II) A graphical presentation of signal amplification by the ternary initiation complexes (SATIC) method for isothermal detection of RNAs. In SATIC, an initiation complex comprising target RNA, a circular DNA template, and a DNA primer is used for rolling circle amplification (RCA). First, the target RNA is hybridized with the complementary sequence of a circular DNA template. Then, a DNA primer starts the strand elongation by $\varphi 29$ DNA polymerase to perform the rolling circle amplification at $37^{\circ} \mathrm{C}$ for $2 \mathrm{~h}$. The RCA-amplified-DNA products acquire secondary structures (known as Gquadruplex (G4) DNA). These G4s are stained with N3-hydroxyethyl thioflavin T (ThT-HE) and emit strong fluorescence, allowing the detection of target RNA in real-time. The method was further extended using two different initiation complexes to enhance the analytical performance. III) A schematic representation of a RNA microarray where the total extracted RNA acts as a template for reverse transcriptase for production of a cDNA library, which were printed on glass slides followed by probe hybridization, microarray scanning, and data processing. I) Reproduced with permission. ${ }^{[114]}$ Copyright 2005, Oxford University Press. II) Reproduced with permission. ${ }^{[139]}$ Copyright 2016, American Chemical Society. III) Reproduced with permission. ${ }^{[123]}$ Copyright 2002, Nature Publishing Group.

on a platform, which hybridize with RNAs of interest for largescale expression analysis (Figure 2III). ${ }^{[33,123]}$ A significant number of microarray-based methods have been developed for genome-wide analysis of RNAs. ${ }^{[3,34,86,123-125]}$ In 2004, Rogler et al. ${ }^{[126]}$ developed a reverse format microarray termed an RNA expression microarray (REM). In REM, total RNAs were initially reverse transcribed to produce a cDNA library. These cDNAs were then printed on a solid support of corning gamma amino propyl (GAP) slides. Humidified hybridization chamber containing mixed Cy3- and Cy5-labeled probes were designed to enable simultaneous hybridization of two genes. The applicability of the REM was tested for the specific detection of albumin, Hnf-4 and Igfbp-1 and c-Myc expression. Zhu et al.[125] developed another method which detected aberrantly expressed 303 lncRNAs and 565 mRNAs in Helicobacter pylori infected cells. Very recently, $\mathrm{Hu}$ et al. ${ }^{[127]}$ reported anther microarray assay to explore the role of miRNAs in gefitinib (a common EGFR inhibitor available as cancer drug) resistance. By using the commercial Agilent miRNA-microarrays, they compared the miRNA expression of a gefitinib-resistant human cell line with its parental cell line (not resistant to gefitinib). The microarray profile revealed that the expression of miR-149-5p was altered in the gefitinib resistant cell line. Further RT-qPCR and biological function tests confirmed the potential involvement of overexpressed miR-149-5p in gefitinib resistance. The microarray method was also used to detect differential expression of ZEB1-AS1 lncRNAs in HCC, ${ }^{[128]}$ where ZEB1-AS1 lncRNA was mostly upregulated in metastatic tumor tissues. Rui et al. ${ }^{[129]}$ performed a microarray profiling of lncRNAs in lymph node metastasis of patients with colorectal cancer. They identified 
the dysregulation of a total of 1133 lncRNA transcripts in metastatic lymph node, compared with normal lymph node. In another microarray study, a total number of 3146 differentially expressed lncRNAs and 2208 mRNAs in sinonasal squamous cell carcinoma with respect to noncancerous tissues were identified. ${ }^{[130]}$ These demonstrations suggest that microarrays are more suitable as discovery tools. ${ }^{[37,121,122]}$

\subsubsection{RNA-seq}

The next-generation sequencing of RNAs (RNA-seq, also known as massively parallel cDNA sequencing) is one of the best alternatives to microarray and RT-qPCR-based methods and has gained a lot of interest in both small- and large-scale analysis of RNAs with greater sensitivity and specificity. ${ }^{[4,35,87,118]}$ Apart from covering a relatively broad range of transcripts, it can also detect mRNA transcript at a single-nucleotide resolution. ${ }^{[18]}$ However, as described by Tavallaie et al., ${ }^{[37]}$ RNA-seq method cannot always reliably quantify circulating miRNAs in a sample with highly varying miRNA distribution pattern.

\subsubsection{RNA Detection by Isothermal Amplifications}

RT-qPCR exponentially amplifies a small amount of target RNA using multiple heating steps (melting steps) during the thermal cycling which is not appropriate for the interrogation of RNA sequences in live cells. ${ }^{[131]}$ To avoid this issue, isothermal nucleic acid amplification strategies, which work at cellular temperatures could be an alternative choice for RNA detection. In the past decades, various types of isothermal amplification-based RNA detection methods have been introduced including reverse transcription loop-mediated amplification (LAMP), ${ }^{[132-134]}$ RNA primed rolling circle amplification (RPRCA), ${ }^{[135,136]}$ signal mediated amplification of RNA technology, ${ }^{[137]}$ and strand displacement amplification. ${ }^{[138]}$

RT-LAMP is a one-step isothermal amplification method that generally provides up to $10^{8}$-fold amplification of single target RNA sequence in $1 \mathrm{~h}$ using a single tube. It uses a set of specially designed primers in combination with the mixture of DNA polymerase and RT. ${ }^{[134]}$ The amplified RNA products can then be detected by a suitable readout method (e.g., visualization with SYBR Green I stain). Horibe et al. ${ }^{[132]}$ developed an RT-LAMP-based assay for detecting lymph node metastasis in gastric carcinoma patients. In this method, RNA was extracted from 92 lymph nodes samples of 9 patients with gastric cancer followed by the isothermal amplification of cytokeratin19 (CK19) mRNA. Among 92 lymph nodes samples, 15 were found to be metastasis-positive, which were further validated with a nested RT-PCR assay. Although the sensitivity of RT-PCR and RT-LAMP is similar, the analysis time in RTLAMP is much faster. On the contrary, the RPRCA method uniquely uses RNA primers instead of DNA primers to avoid the use of reverse transcriptase for detecting small RNAs in a single tube. ${ }^{[135]}$ In RPRCA, usually the target RNA hybridizes to its complementary sequence on a circular DNA template, and is then cleaved by RNase $\mathrm{H}\left(30^{\circ} \mathrm{C}\right)$ followed by elongation (via $\varphi 29$ DNA polymerase at $30{ }^{\circ} \mathrm{C}$ ), amplification, and detection steps. ${ }^{[135,139]}$ In 2016, Fujita et al. ${ }^{[139]}$ developed another RCAbased method referred to as signal amplification by ternary initiation complexes (SATIC) (Figure 2II). In SATIC, a ternary initiation complex was formed among the RNA, circular DNA template, and a DNA primer, followed by RCA at $37^{\circ} \mathrm{C}$. This caused the amplified products to acquire secondary structures producing multiple copies of Gquadruplex (G4) DNA. The G4s were fluorescence-stained with N3-hydroxyethyl thioflavin $\mathrm{T}$ (ThT-HE) for the real-time detection of RNA. The method was further improved using two different ternary initiation complexes in the RCA process to enable the visual observation.

\subsection{RNA Biosensors}

Rapid advancements in nanotechnology have led the development of novel biosensor strategies. Typically an effective biosensor is composed of two major components: i) a receptor (biomolecular recognition species), which specifically recognizes the target analyte, and ii) a transducer (signal-generating and enhancing element) that recognizes the biomolecular interaction and converts this interaction into a measurable signal. ${ }^{[37,140]}$ Over the past several years, several novel biosensors comprising nanopore, optical, and electrochemical readouts have extensively been developed for the quantification and analysis of RNA biomarkers. Starting with a brief outline of optical and nanopore-based biosensors, the remaining part of the review highlights the existing electrochemical sensors.

\subsubsection{Optical Sensors}

Until now, miRNAs, mRNAs, and rRNAs were reported to be analyzed and quantified by optical biosensing strategies where surface plasmon resonance (SPR) and surface enhanced Raman spectroscopy (SERS) readouts have mostly been employed. ${ }^{[39]}$ In SPR, surface immobilized molecular interaction between target RNAs and specific bioreceptor causes a change in the refractive index ,which is measured by the transducer in real-time. It can also explain the molecular interaction of RNA on sensor via analyzing binding kinetics. ${ }^{[39]}$ Sipova et al. ${ }^{[141]}$ developed a labelfree and portable SPR sensor to detect miR-122 from mouse liver tissue. In this method, an additional amplification step was used where the captured miRNA was subsequently recognized by an antibody to enhance the sensitivity of the assay (detection limit was $2 \times 10^{-12} \mathrm{M}$ ). The assay (35 min) was relatively rapid. More recently, Huertas et al. ${ }^{[142]}$ designed another SPR sensor for quantifying cancer-specific alternatively spliced variants of Fas mRNA (Figure 3). This approach is comparable with RT-qPCR in terms of sensitivity and reproducibility. The method is also highly specific due to the use of formamide which significantly reduced the chance of cross hybridization between variants of Fas mRNA. It also uniquely incorporated a sample fragmentation step using RNA alkaline hydrolysis prior the readout to avoid accessibility problems of long mRNA isoforms. The viability of the method was further tested in HeLa cancer cell lines.

On the other hand, SERS-based methods depend on the quantification of surface plasmon excitation in metallic 


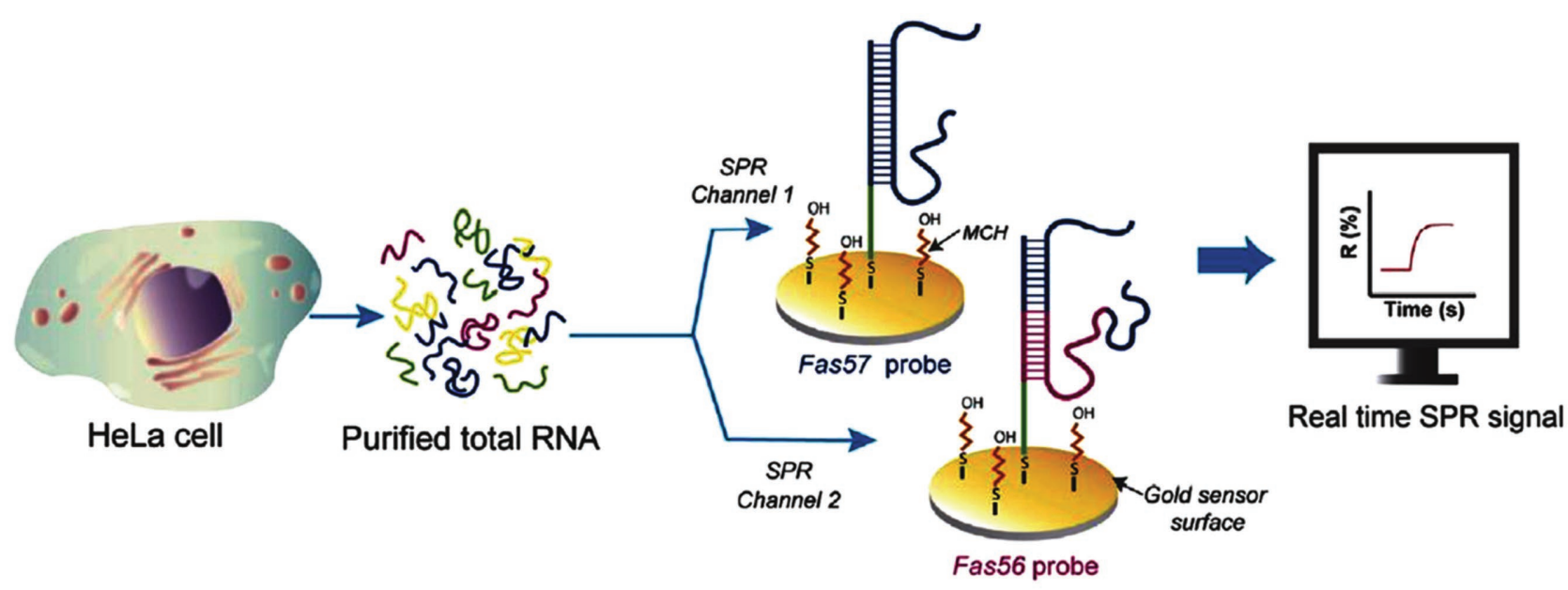

Figure 3. Real-time and label-free analysis of alternative spliced variants of Fas mRNA by an SPR sensor. Purified total RNA, extracted from HeLa cells, is passed through two specially designed SPR channels. Each channel is functionalized with one DNA-probe, which is complementary to the splicejunctions of the Fas gene isoforms (either Fas567 or Fas57). Under optimized functionalization and detection conditions, real-time binding of the targets and the resulting change in the refractive index are monitored. Reproduced with permission. ${ }^{[142]}$ Copyright 2016, Elsevier.

nanostructures of SERS substrates, which has been used for analyzing different RNA biomarkers including fusion mRNA. ${ }^{[143-145]}$ Very recently, Wang et al. ${ }^{[143]}$ demonstrated the application of a "turn-on" SERS method referred to as "inverse Molecular Sentinel (iMS)" nanoprobes, for multiplexed detection of miRNAs. In this method, the SERS probes used plasmonic-active nanostars as the sensing platform where the "OFF-to-ON" signal switch relied on the conformational change of stem-loop (hairpin) capture probes during target hybridization. The clinical applicability of the assay was tested in breast cancer cell lines using a mixture of the two differently labeled nanoprobes to detect miR-21 and miR-34a biomarkers respectively.

In 2007, Seferos et al. ${ }^{[146]}$ introduced a fluorescence method for mRNA analysis which used a novel intracellular RNA probe termed as "Nanoflares." Nanoflares has the unique feature of transfecting into the live cells for visualizing and quantifying mRNA. First, 13-nm gold nanoparticles (AuNPs) were functionalized with thiolated oligonucleotides (acting as the recognition element for mRNA transcripts) to develop the nanoflares. Then, a short reporter sequence tagged with cyanine (Cy5) dye was hybridized with functionalized AuNPs. This reporter sequence was considered as "flares" in the nanoflares sensor. In the absence of target, the Cy5 dye is quenched due to proximity to the AuNP surface. However, when target RNA is present, a robust duplex is formed between the RNA and nanoflares which causes the removal of flare from the AuNP, providing measurable fluorescence readout. The method was successfully tested in a synthetic target and a real sample for the realtime quantification of mRNA. One obvious disadvantage of the existing transfecting agents (e.g., lipids and dendrimers) for RNA analysis is that they can produce toxicity inside the cell. Furthermore, oligonucleotides-based transfecting agents are unstable inside the live cells due to their enzymatic degradation, primarily via the action of $3^{\prime}$ exonucleases. This instability of oligonucleotides inside the live cell and other associated issues were critically reviewed by Opalinska et al.[147] Nanoflares, on the contrary, are not toxic and are highly stable inside the cells. Nanoflares thus have very high potential in detecting RNAs from live cells and have already been incorporated in several RNA biosensing approaches. ${ }^{[148,149]}$

\subsubsection{Nanopore Sensors}

Nanopore sensing tools are one of the most prominent singlemolecule sensors. Typically, in the presence of a conducting fluid, when a potential is held, nanopores produce electric current due to the charge transport in the holes. The produced current is highly sensitive to the size and physical properties of the pore. Thus, detectable current changes can be observed when the target analyte (e.g., RNA) is trapped inside the pore after hybridization with a target specific capture probe. ${ }^{[150,151]}$ Until now, only miRNAs have been interrogated via nanopores. ${ }^{[152-155]}$ Wang et al. ${ }^{[155]}$ developed a unique nanopore sensor using $\alpha$-hemolysin protein pore (Figure 4$)$. The method relied on the translocation of single-stranded oligonucleotides through the $2 \mathrm{~nm}$ sized pore functionalized with a programmable oligonucleotide probe. Both ends of this oligonucleotide probe were attached with a poly $(\mathrm{dC})_{30}$ signal tag, which then became highly specific for target miRNA and thus avoided their cross-hybridization with nonspecific RNAs. Depending on the presence of specific miRNA, a measurable signal was obtained. The method also showed highly sensitive detection limit of $100 \times 10^{-15} \mathrm{M}$. Additionally, the sensor was successfully tested to differentiate the relative levels of miR-155 of healthy and lung cancer patients. A comparative analysis of the advantages, disadvantages, and analytical functionalities of the nanopore sensors along with other major RNA detection platforms ${ }^{[39,102,123,152,154,156-161]}$ is summeaized in Table 2.

\subsubsection{Electrochemical Biosensors}

In recent years, significant progress has been made toward the development of electrochemical methods to interrogate 
a

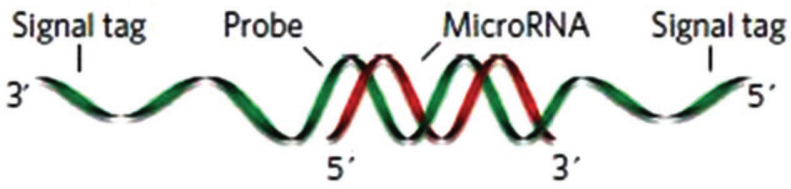

b
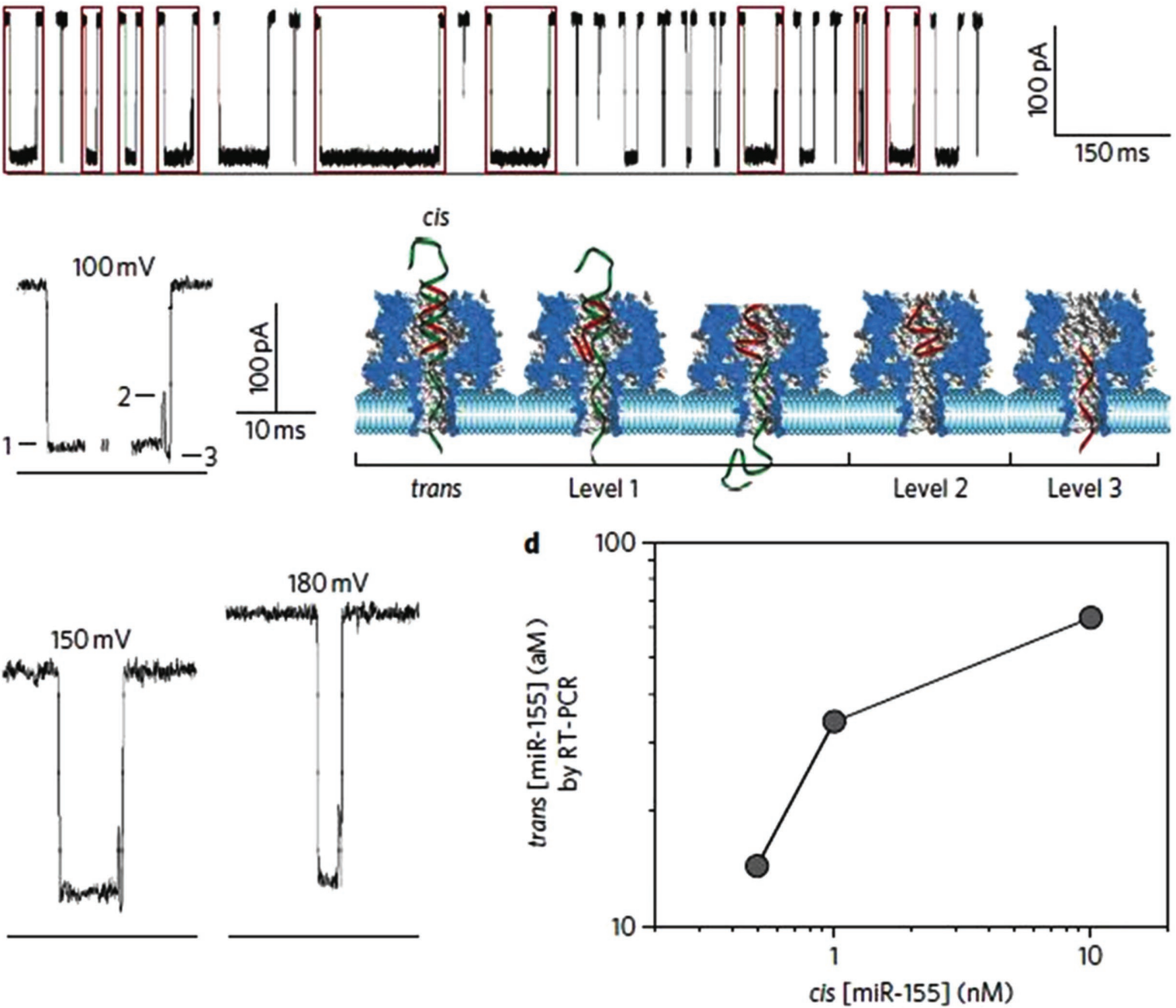

e

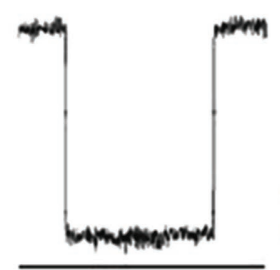

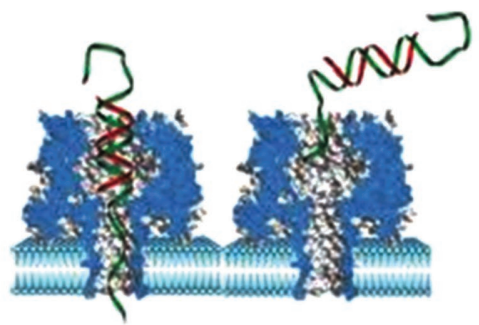

$\mathbf{f}$

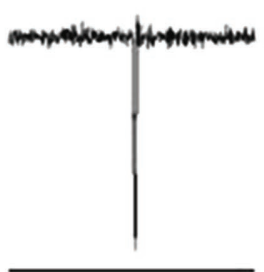

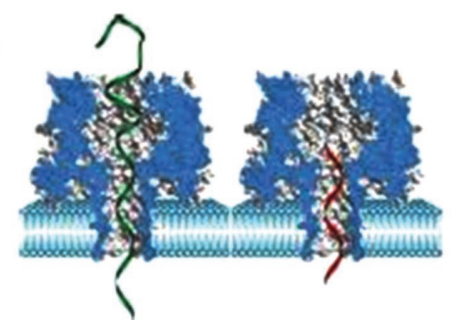

Figure 4. A schematic diagram of lung-cancer-related single-miRNA-molecule (miR-155) capture by a nanopore. a) A microRNA (red) hybridized to a probe (green) having signal tags on both ends. b) Diagram of current blocks in the nanopore, in the presence of $100 \times 10^{-9} \mathrm{M} \mathrm{miR-155} \mathrm{and} \mathrm{its} \mathrm{capture}$ probe $\mathrm{P}_{155}$ on the cis side of the pore. The red boxes denote the multilevel current pattern resulting from the hybridization of target miR-155 with the capture probe. c) A typical multilevel long block of hybridized miR-155 at $+100 \mathrm{mV}$. Right panel: molecular mechanism of hybrid dissociation and translocation. Level 1: Capture of the target-probe hybrid, unzipping of the target miRNA from the probe followed by the translocation of the probe. Level 2: Unzipped microRNA staying inside the pore. Level 3: Translocation of the unzipped microRNA through the pore. Lower panel: multilevel current blocks at +150 and $+180 \mathrm{mV}$ where the duration of Levels 1 and 3 is decreased with increasing the potential supporting the functionality of the nanopore model. d) Quantification of miR-155 levels detected by RT-qPCR in trans solutions once the electrical readout is taken. e) A single-level block (from (b)) generated by a trapped miR-155-probe hybrid (without unzipping and translocation). f) A spike-like short block generated by the translocation of unhybridized miR-155 or probe from the cis solution. Reproduced with permission. ${ }^{[155]}$ Copyright 2011, Nature Publishing Group. 
Table 2. Major detection platforms for RNA biomarkers.

\begin{tabular}{|c|c|c|c|c|c|}
\hline $\begin{array}{l}\text { Detection platform } \\
\text { or assay }\end{array}$ & Detection principle & Advantages & Disadvantages & $\begin{array}{l}\text { Amount of RNA } \\
\text { required or } \\
\text { LOD }\end{array}$ & References \\
\hline $\begin{array}{l}\text { Quantitative reverse } \\
\text { transcription PCR } \\
\text { (RT-qPCR) }\end{array}$ & $\begin{array}{c}\text { Reverse transcription of RNAs to CDNA } \\
\text { followed } \\
\text { by quantitative PCR }\end{array}$ & $\begin{array}{c}\text { Established method, sensitive, specific, } \\
\text { sensitive, ideal for small RNAs, widely } \\
\text { available and compatible with laboratory } \\
\text { workflows, }\end{array}$ & $\begin{array}{l}\text { Expensive, not suitable } \\
\text { for high throughput RNA } \\
\text { screening and discovery } \\
\text { studies, effective only } \\
\text { against established RNAs }\end{array}$ & $\begin{array}{l}\text { Input RNA, } \\
<\text { ng or ng- } \mu g\end{array}$ & {$[102,156,157]$} \\
\hline Microarray & $\begin{array}{l}\text { Hybridization of RNA with complementary } \\
\text { probes } \\
\text { prefabricated in the thousands of spots } \\
\text { on a microarray platform }\end{array}$ & $\begin{array}{c}\text { Established method, relatively inexpensive, } \\
\text { high throughput screening, suitable for } \\
\text { discovery studies }\end{array}$ & $\begin{array}{l}\text {, Relatively lower specificity } \\
\text { and sensitivity, no } \\
\text { absolute quantification, } \\
\text { cannot efficiently dis- } \\
\text { criminate closely related } \\
\text { miRNAs }\end{array}$ & $\begin{array}{l}\text { Input RNA, } \\
\text { ng- } \mu g\end{array}$ & {$[102,123,156,157]$} \\
\hline RNA sequencing & $\begin{array}{c}\text { Preparation of cDNA library from target } \\
\text { RNAs followed by "massively parallel" } \\
\text { sequencing } \\
\text { of library derived cDNA }\end{array}$ & $\begin{array}{l}\text { Can distinguish miRNAs from closely } \\
\text { related RNAs and precursors }\end{array}$ & $\begin{array}{l}\text { Extensive bioinformatics } \\
\text { supports required, } \\
\text { suitable only for relative } \\
\text { quantification }\end{array}$ & $\begin{array}{l}\text { Input RNA, } \\
\text { ng- } \mu \mathrm{g}>\mathrm{ng}\end{array}$ & {$[102,123,156,157]$} \\
\hline $\begin{array}{l}\text { Surface Plasmon } \\
\text { resonance } \\
\text { (SPR) }\end{array}$ & $\begin{array}{l}\text { Measurement of refractive index (RI) } \\
\text { changes resulting } \\
\text { from the surface } \\
\text { immobilized molecular interaction between } \\
\text { RNAs and bioreceptor }\end{array}$ & Real-time and label- free analysis & $\begin{array}{l}\text { Low throughput, higher } \\
\text { sample input, longer } \\
\text { assay time }\end{array}$ & $\begin{array}{l}\text { Input RNA, } \\
\text { ng- } \mu \mathrm{g}\end{array}$ & {$[39,158]$} \\
\hline Nanopore & $\begin{array}{l}\text { The charge transport in the nanopore is } \\
\text { halted in the } \\
\text { presence RNA target of interest. The resul- } \\
\text { tant blockade } \\
\text { current is quantified }\end{array}$ & Sensitive, single molecule sensor & $\begin{array}{l}\text { Complicated sensor fab- } \\
\text { rication, not suitable for } \\
\text { detecting long RNAs }\end{array}$ & $\begin{array}{l}\text { Input RNA, } \\
\text { ng- }-\mu \mathrm{g}\end{array}$ & {$[152,154]$} \\
\hline \multirow[t]{4}{*}{$\begin{array}{l}\text { Electrochemical } \\
\text { sensors }\end{array}$} & $\begin{array}{c}\text { a) Cisplatin-biotin labeled mRNA/redox } \\
\text { polymer bilayer on a gold electrode. Enzy- } \\
\text { matic oxidation of glucose oxidase-avidin } \\
\text { molecules produce detectable amperometric } \\
\text { signal }\end{array}$ & $\begin{array}{l}\text { a) Amplification free, highly sensitive, low } \\
\text { sample input (5 ng) }\end{array}$ & $\begin{array}{l}\text { a) Multistep sensor } \\
\text { fabrications }\end{array}$ & $\begin{array}{l}\text { a) LOD, } 0.05 \times \\
10^{-15} \mathrm{M}\end{array}$ & [159] \\
\hline & $\begin{array}{l}\text { b) Target mRNA induced conformational } \\
\text { change of hairpin }(\mathrm{HP}) \text { probe results in a } \\
\text { readable electrochemical signal }\end{array}$ & $\begin{array}{l}\text { b) Amplified signal, efficient capture (HP } \\
\text { probe is thousands fold sensitive than } \\
\text { linear capture probe) }\end{array}$ & $\begin{array}{l}\text { b) Not tested in complex } \\
\text { biological sample }\end{array}$ & $\begin{array}{l}\text { b) LOD, } 0.4 \times \\
10^{-15} \mathrm{M}\end{array}$ & [160] \\
\hline & $\begin{array}{l}\text { c) Target fusion mRNA is captured on amino } \\
\text { acid/nucleic acid chimeras (ANAs) capture } \\
\text { probe functionalized gold microelectrodes. } \\
\text { Voltammetric readings enable the detection } \\
\text { in the presence of }\left[\mathrm{Ru}(\mathrm{NH} 3)_{6}\right]^{3+} /\left[\mathrm{Fe}(\mathrm{CN})_{6}\right]^{3-} \\
\text { redox probe }\end{array}$ & $\begin{array}{l}\text { c) Simultaneous screening multiple RNA } \\
\text { targets, ANA capture probe facilitates low } \\
\text { background response and stable mono- } \\
\text { layer formation on microelectrodes }\end{array}$ & $\begin{array}{l}\text { c) Complicated and mul- } \\
\text { tistep sensor fabrications }\end{array}$ & $\begin{array}{l}\text { c) } \operatorname{LOD}, 1.0 \mathrm{pg} \\
\mu \mathrm{L}^{-1}\end{array}$ & [161] \\
\hline & $\begin{array}{l}\text { d) Direct adsorption of magnetically cap- } \\
\text { tured target fusion RNAs on the unmodified } \\
\text { screen-printed gold electrodes via RNA-gold } \\
\text { affinity interaction. Resultant coulombic } \\
\text { repulsion between negatively charged RNA } \\
\text { and ferricyanide ions produce detectable } \\
\text { voltammetric signal. }\end{array}$ & $\begin{array}{l}\text { d) Significantly simplified sensor, avoids } \\
\text { conventional surface modification and } \\
\text { probe immobilization steps on electrode, } \\
\text { relatively inexpensive, highly specific, } \\
\text { amplification free, noninvasive screening }\end{array}$ & $\begin{array}{l}\text { d) Not suitable for long } \\
\text { RNAs }\end{array}$ & $\begin{array}{l}\text { d) Target fusion } \\
\text { mRNA can be } \\
\text { detected from } \\
\text { minimum } 10 \\
\text { cancer cells }\end{array}$ & [41] \\
\hline
\end{tabular}

clinically relevant RNAs. ${ }^{[37,40,44,161]}$ Most of these methods are based on the hybridization of target RNA sequences to the surface bound complementary receptor probes (mostly DNA oligonucleotides) on the electrode. The hybridization of RNAs with probes results in a measurable electrochemical signal. Here, signal transduction relies on various factors including intrinsic electroactivity of nucleobases, and the presence of redox indicators (e.g., intercalators such as methylene blue), covalently bound redox labels (e.g., nanoparticles), or reporter enzymes (e.g., phosphatases, peroxidases). ${ }^{[40,162]}$ Then, the detection of RNAs is mostly read via voltammetric, amperometric, and impedimetric approaches. ${ }^{[40,163]}$ In parallel to these, few ultrasensitive electrochemical approaches have also been developed using chip-based nanostructured microelectrodes for multiplexed detection of RNA biomarkers. ${ }^{[161,164,165]}$ In these chipbased sensors, nanostructured electrodes are usually deposited 
on the surface of the chip using photolithography which work as specific detector for multiplexed analysis.

Electrochemical Biosensing of Coding RNAs: Due to the crucial role of coding RNAs (i.e., mRNA) in disease diagnosis and prognosis, several novel electrochemical sensors aiming to detect and analyze mRNA biomarkers have been developed. ${ }^{[40,41,159-161,166-168]}$ One of the earliest mRNA-detection methods was demonstrated by Xie et al. ${ }^{[159]}$ (Figure 5I). In this method, first, total extracted RNA was directly labeled with cisplatin-biotin and allowed to hybridize with a thiolated oligonucleotide capture probe, which was functionalized on a gold electrode. Following hybridization of target mRNA on the electrode surface, glucose oxidase-avidin molecules were introduced in the system which conjugated with biotinylated target mRNA via the biotin-avidin interaction. Then, the electrode surface was coated with a cationic redox polymer containing osmium-bipyridine. Since the target mRNA is attached with glucose, the current generated from enzymatic oxidation of glucose was directly proportional to the target mRNA concentration in the sample. The viability of this highly sensitive method was tested for the detection of GAPDH and cancer-specific $p 53$ mRNA (LOD, $0.5 \times 10^{-15} \mathrm{M}$ ). Moreover, a partially complementary capture probe (single base mismatch) was introduced in the sensor, which produced notable drop in the amperometric response, supporting the excellent specificity of the assay.

The hairpin (HP) DNA probe is one of the most versatile oligonucleotide probes for biomarkers screening and is commonly being used in optical and electrochemical assays for RNA detection. ${ }^{[160]}$ The loop area of the hairpin probe is selectively designed to be complementary to the target RNA sequences. When RNA is hybridized with the HP probe, the stem loop structure of the HP opens up allowing the prefunctionalized electroactive reporter molecule to interact, resulting in a detectable signal. For example, Wei et al. ${ }^{[160]}$ incorporated an $\mathrm{HP}$ probe on a gold electrode in a "signal on" electrochemical method and successfully detected interleukin (IL)-8 (a potential noninvasive biomarker for oral cancer) mRNA from saliva. In this approach, the $3^{\prime}$ end of the HP probe was tagged with a fluorescein molecule while the 5 'biotinylated end was immobilized on the streptavidin modified gold electrode to give the probe a stem loop structure. In the absence of target mRNA, resultant steric hindrance inhibits the binding of the anti-fluorescein-HRP conjugate on the electrode surface thereby ceasing further reaction. When target mRNA is present, the hairpin opens up and then, in the presence of the TMB substrate, the bound HRP produces an amplified electrochemical signal. This signal is directly correlated with the amount of target mRNA present in the sample. The method was relatively fast and attained very high sensitively $\left(\approx 0.4 \times 10^{-15} \mathrm{M}\right)$. The method was later extended for the multiplexed detection of mRNA. ${ }^{[167]}$ In a similar approach, a switchable "on-off-on" technique involving a stem-loop oligonucleotide probe was used for the detection of tumor-specific survivin mRNA. ${ }^{[169]}$

One of the foremost challenges of RNA biomarker detection in clinical application is to simultaneously screen the very low amount of readily available RNA biomarkers in complex heterogeneous samples, which could contain many nonspecific targets. These challenges could be addressed via the multiplexed and highly sensitive analysis of RNAs by employing novel nanostructured electrochemical sensors. ${ }^{[161,164,165]}$ For example, Vasilyeva et al. ${ }^{[161]}$ developed a sensor for the analysis of cancerspecific mRNA fusion using an array of nanostructured gold microelectrodes. In this method, a novel capture probe, termed as amino acid/nucleic acid chimeras (ANAs), was immobilized onto the surface of microelectrodes. ANAs significantly enhance the assay performance compared to the existing neutral capture-probe-based assay. This is due to the fact that ANA has relatively good solubility along with the ability of forming stable monolayer on the sensor. The ANA also specifically can recognize and binds at the junction of gene fusion. In the presence of $\left[\mathrm{Ru}(\mathrm{NH} 3)_{6}\right]^{3+} /\left[\mathrm{Fe}(\mathrm{CN})_{6}\right]^{3-}$ redox probe, the concentration of hybridized mRNA was measured from the voltammetric readout. To illustrate the applicability of the sensor, chronic myeloid leukemia specific BCR-ABL mRNA fusion was detected in cancer cell lines. When very high concentration of the partially complementary capture probe was used along with the fully complementary BCR-ABL probe, the electrochemical signal for the complementary targets was unaffected, showing the high specificity of the assay.

Apart from BCR-ABL, several other fusion mRNAs (e.g., TMPRSS2-ERG) have attracted significant interest as cancer biomarkers due to their role in cancer development and high specificity (Mertens 2015). ${ }^{[170]}$ Fusion mRNA is transcribed from fusion gene as the product of chromosomal rearrangements such as translocations, insertions, inversions, and interstitial deletions where two genes from each side of chromosomal breakpoint may fuse together ${ }^{[170,171]}$ In addition, the coding sequences in one gene can be juxtaposed with the regulatory sequences of another gene to form the fusion gene. ${ }^{[170]}$ Approximately $20 \%$ of all types of human cancers are associated with the fusion mRNAs. ${ }^{[172]}$ For example, the TMPRSS2ERG fusion mRNA (originated from mutation between the TMPRSS2 promoter sequence and the ERG coding sequence) is uniquely expressed in $\approx 50 \%$ of malignant prostate cancer cases and considered as one of the finest selective biomarkers of prostate cancer for their aberrant role in the inhibition of the apoptosis of prostate gland cells. ${ }^{[59,173]}$

More recently, Koo et al. ${ }^{[41]}$ have developed an amplificationfree method for detecting prostate cancer specific TMPRSS2: ERG mRNA fusion (Figure 5II). This method avoids the complicated chemistries underlying the conventional multistep sensor fabrication steps thereby significantly simplifying the sensor design. Moreover, the method recruited patients' urine samples to extract the TMPRSS2: ERG mRNA for electrochemical interrogation, which offered a significant improvement in the noninvasive screening of prostate cancer patients. In this method, first, RNA was extracted and purified from patient urine samples. TMPRSS2: ERG mRNA transcripts were then selectively captured by the biotinylated capture probe in the solution. Next, streptavidin-coated magnetic nanoparticles were dispersed into the reaction mixture. After magnetic purification, the captured mRNA fusion was directly adsorbed on the commercially available screen-printed gold electrodes via the RNA-gold affinity interaction. ${ }^{[174]}$ The adsorbed mRNA (negatively charged) creates higher Coulombic repulsion toward the negatively charged ferricyanide ions thereby resulting in a decreased electrochemical signal compared to that of control and normal sample. The method showed excellent specificity in 
(I)
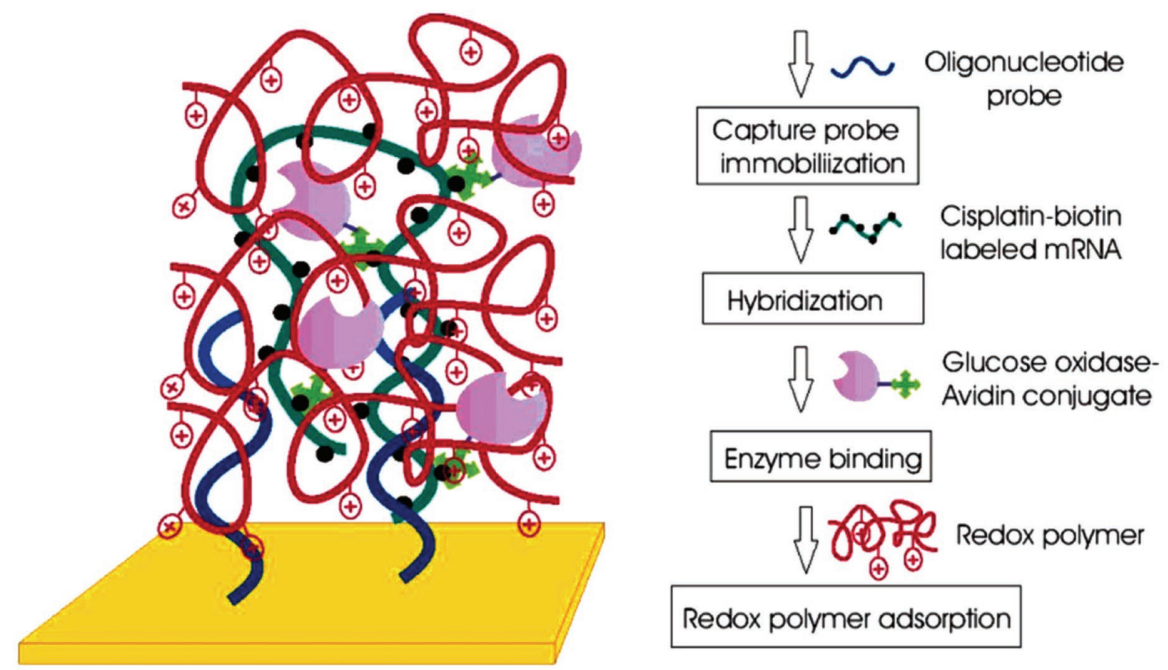

Redox polymer adsorption

(II)

a

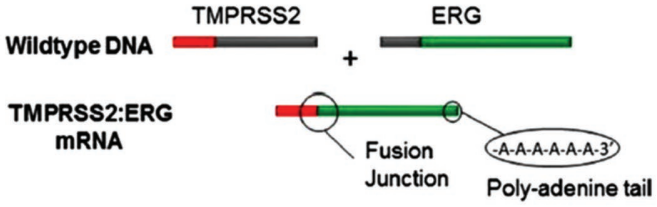

b

(20)
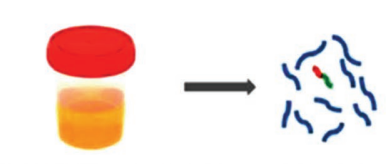
Capture Probe

Patient Urine Sample

Total RNA
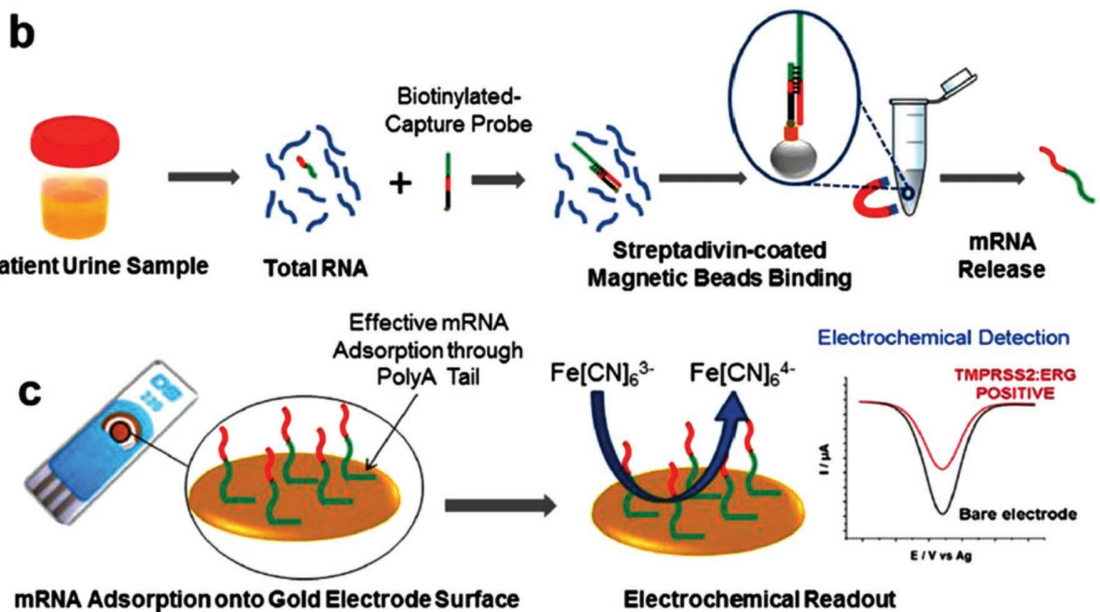

Figure 5. Electrochemical detection of coding RNAs. I) Schematic illustration of an mRNA detection assay using an mRNA/redox polymer bilayer model: cisplatin-biotin labeled mRNA is hybridized with a thiolated oligonucleotide capture probe functionalized on a gold electrode. Glucose oxidase-avidin molecules are then introduced in the system, which binds the biotinylated target mRNA via a biotin-avidin interaction. Then, the electrode surface is coated with a cationic redox polymer which mediates the enzymatic oxidation of glucose. As the target mRNA is attached with glucose, the amperometric current generated from its oxidation is directly proportional to the mRNA concentration in the sample. II) Steps involved in an amplification-free detection of prostate-cancer-specific TMPRSS2:ERG mRNA using the mRNA-gold affinity interaction: a) TMPRSS2:ERG mRNA is the fusion between the TMPRSS2 promoter sequence and the ERG coding sequence; b) total RNA is extracted from urine samples followed by specific capture of TMPRSS2:ERG mRNA via a biotinylated capture probe. The target is then magnetically isolated from the sample pool using streptavidincoated magnetic beads; $c$ ) the magnetically captured target mRNA is heat-released and adsorbed on an unmodified screen-printed gold electrode. The presence of mRNA is analyzed by differential pulse voltammetry in the presence of the $\left[\mathrm{Fe}(\mathrm{CN})_{6}\right]^{4-/ 3-}$ redox system. I) Reproduced with permission. ${ }^{[159]}$ Copyright 2004, American Chemical Society. II) Reproduced with permission. ${ }^{[4]}$ Copyright 2016, American Chemical Society.

detecting TMPRSS2: ERG mRNA while a negative control cell line (TMPRSS2: ERG fusion gene absent) was used. Until now, the most preferable approach for identifying cancer associated fusion transcripts is the next-generation sequencing (NGS), especially RNA-seq. ${ }^{[171]}$ However, the detection of fusion mRNA by RNA-seq has been limited by the resultant false-positives response. ${ }^{[118,175,176]}$ Moreover, RNA seq for fusion mRNA heavily relies on the complicated data analysis procedure with various type of software packages. This was also supported by a recent study from Kumar et al. ${ }^{[176]}$ who observed substantial variation in the NGS data analyzed by different fusion-mRNAdetection software tools. In this regard, the amplification-free 
and nonenzymatic electrochemical method has clear advantages over RNA-seq for acquiring relatively accurate detection of fusion mRNAs.

Electrochemical Biosensing of Regulatory RNAs (Noncoding RNAs): The principle of electrochemical biosensing of miRNAs is almost the same as that of DNA or mRNA hybridization biosensors. One example of miRNA detection strategies is the direct oxidation-based analysis of circulating miRNA bases. ${ }^{[177]}$ In this method, miR-122 was hybridized with its inosine substitute capture probe on a carbon-based nanostructured electrode. Electroactive polymers were also used on the electrode to increase the electroactive area and reduce the electrical resistance. Then, direct oxidation of guanine during RNA hybridization resulted in a measurable differential pulse voltammetric (DPV) signal. This method significantly improved the limit of detection of circulating miRNAs in serum $\left(10 \times 10^{-15} \mathrm{M}\right)$. The detection limit was further improved $\left(100 \times 10^{-18} \mathrm{M}\right)$ in patient serum via the development of a DNA-concatemer-based ultrasensitive electrochemical method. ${ }^{[178]}$ In this approach, two auxiliary probes were self-assembled to form a one-dimensional DNA concatemers. An HP capture probe was immobilized on the surface of screen-printed gold electrodes. In the absence of target miR-21, the HP probe retained its loop structure offering no binding site for the DNA concatemers. This produced little electrochemical signals. However, when miR-21 was present, the stem-loop structure of the HP capture probe opened up, allowing their hybridization with DNA concatemers. Next, the RuHex signal reporter bound to the negatively charged DNA concatemers on the working electrode significantly amplified the electrochemical signal enabling the detection.

Different intermediates of miRNA biogenesis such as primiRNA, pre-miRNA, and other small noncoding RNAs such as rRNA share sequence similarities with miRNAs. During miRNA detection, these nonspecific RNA molecules can interfere with the target miRNA via cross-hybridization resulting in false-positive response. ${ }^{[179]}$ This issue was addressed via the incorporation of a special RNA binding protein known as p19 in the sensor. ${ }^{[180]}$ Usually, the p19 protein works as a molecular caliper of small double-stranded RNA (21-23 base pairs) and isolates miRNAs in a size-dependent and sequence-independent manner. Being more specific, the p19 protein does not bind to ssRNA, rRNA, mRNA, ssDNA, or dsDNA whereas it can specifically bind to the double-stranded miRNA. ${ }^{[179]}$ Thus the inclusion of p19 in the reaction mixture can significantly reduce the chance of nonspecific detection. Using this exclusive property of p19 protein, a three-mode electrochemical sensor was developed for the detection of circulating miRNAs. ${ }^{[43]} \mathrm{A}$ schematic representation of this three-mode sensor is presented in Figure $\mathbf{6}$. The three-way analysis detects one or multiple miRNAs on gold-nanoparticle-modified screen-printed carbon electrodes by using square wave voltammetry (SWV) in the incubation buffer containing $\mathrm{K}_{3}\left[\mathrm{Fe}(\mathrm{CN})_{6}\right]$ and $\left[\mathrm{Ru}\left(\mathrm{NH}_{3}\right)_{6}\right]$ $\mathrm{Cl}_{3}$. In the first modality, the hybridization of the target miR-21 to its complementary thiolated-immobilized probe causes a modulation of the SWV signal (Figure 6b). A linear range of detection was found from $1 \times 10^{-15} \mathrm{M}$ to $10 \times 10^{-12} \mathrm{M}$. In the second modality, the 19 protein dimer was added to the formed hybrid. This amplifies the SWV signal and allows an ultrasensitive detection of the miR-21 (i.e., linear detection range to $10 \times 10^{-18} \mathrm{M}$ to $10 \times 10^{-15} \mathrm{M}$ ) via binding of the bulky p19 protein and consequently shielding the electrode surface (Figure $6 \mathrm{c}$ ). In the third modalities, a universal displacementbased sensor is formed on the basis of the self-assembled thiolated RNA probe bound to the saturation concentration of a miRNA, whereas the p19 is attached to the formed hybrid. Subsequently, a mixture of a new target miRNA (here miR-200) and its complementary nonthiolated-RNA probe is incubated with the p19-modified sensor. Because the nonthiolated-RNA probe is complementary to the miR-200 sequence, a newly formed hybrid at relatively higher concentration compared to the concentration of the immobilized hybrid can force the p19 protein to dissociate from the immobilized hybrid on the electrode surface, and to bind to the newly formed hybrid causing a shiftback of the SWV signal (i.e., the linear detection range to $100 \times 10^{-12}$ to $\left.1 \times 10^{-6} \mathrm{M}\right)$. This displacement-based sensor can therefore be employed for detection of any type of miRNA without the need of a thiolated capture probe (Figure 6d). Moreover, the sensor can distinguish miRNAs with different $\mathrm{A} / \mathrm{U}$ and $\mathrm{G} / \mathrm{C}$ content and differentiate single base mismatch in miRNAs.

The emerging functional insights of long noncoding RNAs in gene regulation has triggered extensive studies in the translational clinical research field. ${ }^{[12,26,51,84]}$ Despite the huge clinical significance of lncRNAs, their electrochemical detection is not well explored. Until now, only a few reports on electrochemical biosensing of lncRNAs are available. ${ }^{[181,182]}$ This could be explained by the fact that lncRNA has a relatively long sequence with a high molecular weight. Moreover, due to the presence of an extra oxygen atom in RNA sugar, lncRNAs tend to interact with the nucleic acid backbone via hydrogen bonding, resulting in secondary or tertiary structures (i.e., hairpin, triplexes, and quadruplexes structures). Taken together these issues, the commonly used RNA-hybridization-based electrochemical sensors cannot recognize and effectively capture the target lncRNAs on the electrode surface. In 2015, Liu et al. ${ }^{[182]}$ used the catalytic amplification ability of single-wall carbon nanotubes coated with Au-Rh hollow nanospheres (Au/Rh-HNP@SWCNT) to detect nuclear paraspeckle assembly transcript 1 (NEAT1) lncRNA, which is reportedly overexpressed in patients with HIV. The nanospheres have the combined benefits of RNA binding features of gold, unique electronic properties, and large edge-plane-to-basal-plane ratio of single-wall carbon nanotubes (SWCNTs), and the surpassing catalytic properties of Rh. In this sensor, the gold ( $\mathrm{Au}$ ) electrode was first modified with L-cysteine followed by the formation of a $\mathrm{Au}$ monolayer by the electrodeposition of an L-cysteine-containing gold electrode in a colloidal solution of $\mathrm{Au}$ nanoparticles. The nanomaterial (Au/Rh-HNP@SWCNT complex) tagged capture probe (RNA fragment containing a (GGGG) quadruplex) was then allowed to bind with each possible site of AuNPs. To avoid nonspecific binding, the sensor was soaked with hexanethiol. Finally the sensor was incubated with hemin solution where quadruplex containing target RNA binds with hemin resulting in a higher (catalytic) redox signal of hydrogen peroxides in the presence of HRP, allowing the quantification of NEAT1. 


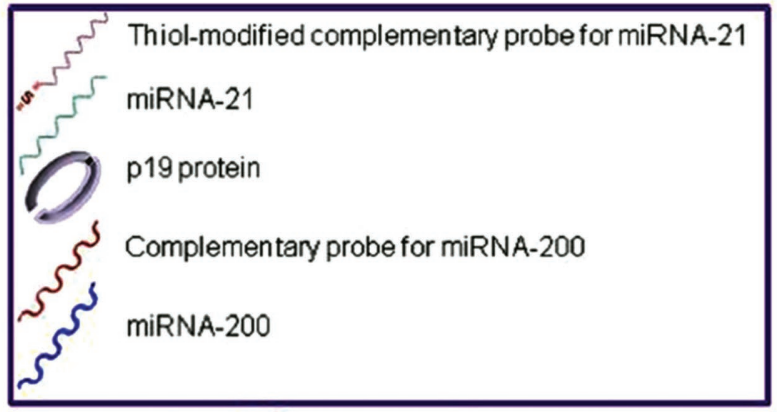

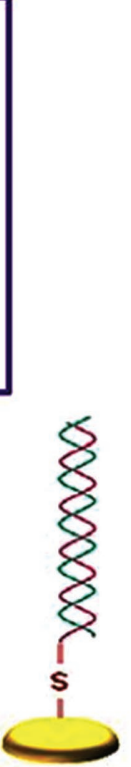

(b)

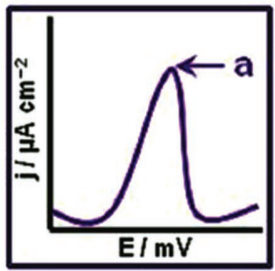

(a)
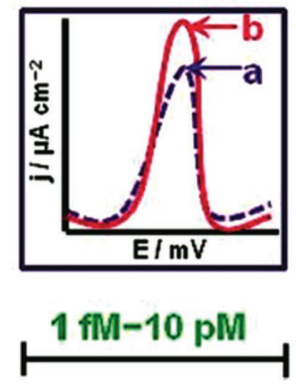
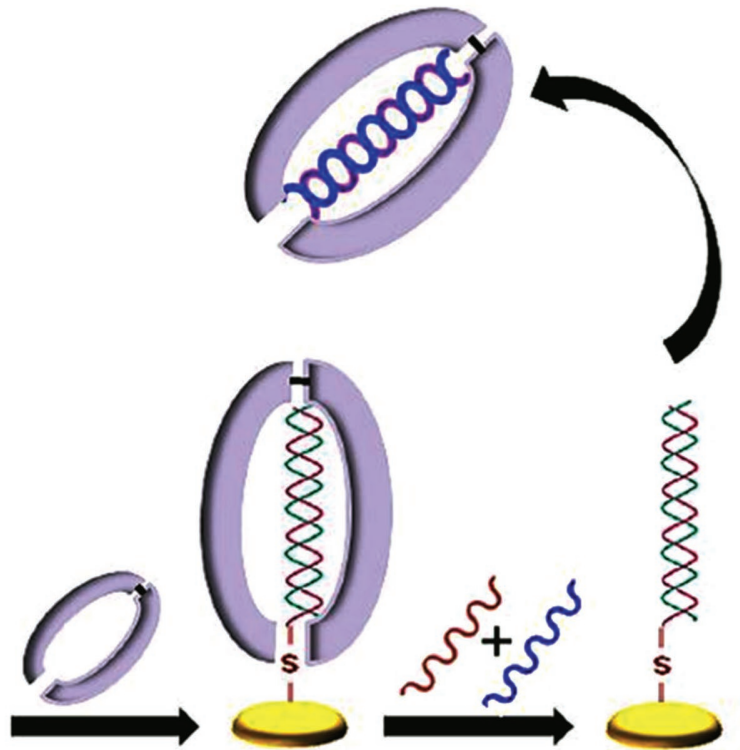

(c)

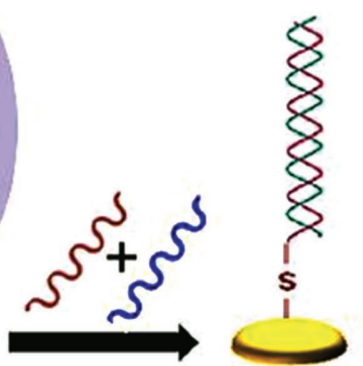

(d)

Figure 6. Three-mode electrochemical biosensor for multiple miRNA detection: first: a) a thiolated capture probe complementary to the target miR-21 is self-assembled onto a gold-nanoparticle-modified screen-printed carbon electrode; $b$ ) the target miR-21 is hybridized with the thiolated probe causing an enhancement of the square wave voltammetric current (SWV); second: c) the binding of the p19 protein dimer to the formed hybrid attenuates the SWV signals due to the shielding the electrode surface; and third: d) in the presence of a newly formed hybrid between the target miR-200 and its nonthiolated complementary probe at high concentration, p19 protein is dissociated from the immobilized hybrid on the electrode surface and to bind to the newly formed hybrid causing a shiftback of the signal. Electrochemical measurements were performed in the incubation buffer containing $4 \times$ $10^{-3} \mathrm{M} \mathrm{K}_{3}\left[\mathrm{Fe}(\mathrm{CN})_{6}\right]$ and $10 \times 10^{-6} \mathrm{M}\left[\mathrm{Ru}\left(\mathrm{NH}_{3}\right)_{6}\right] \mathrm{Cl}_{3}$. Reproduced with permission. ${ }^{[43]}$ Copyright 2013, The American Chemical Society.

\section{Conclusions}

Here, we have provided an overview of the current progress of RNA-detection technologies with special emphasis on the development of electrochemical biosensors. The major challenges involved in these strategies along with the diagnostic and prognostic significance of clinically relevant RNAs have also been discussed. It has been shown that tumor-derived circulating RNAs can work as a liquid biopsy for the minimally invasive diagnosis of cancer, resulting in less patient discomfort. Although, their high stability in clinical samples has triggered huge interest, necessary caution should be taken to ensure the minimal sample preprocessing of these RNA biomarkers to retain their high stability.

From the representative examples of different detection technologies, it is apparent that RNA biosensors usually involve the hybridization of target RNA with a capture probe followed by a suitable readout method such as electrochemical readout.
Despite the significant progress made in these electrochemical methods, still major work needs to be performed to achieve a biosensor suitable for a point-of-care platform. This is because most biosensors are merely proof-of-concept demonstrations and highly dependent on complex sensor fabrications and a series of optimization steps in a well-equipped laboratory setup. To translate these laboratory-based proof-of-concept demonstrations to clinical applications in real-world settings, there are many outstanding hurdles. One of the major issues is the false-positive detection of RNAs due to nonspecific bindings. To avoid this, an optimized sample extraction protocol and the development of innovative sensors are urgently required. Nonetheless, we have seen that several unique methods have attempted to address these requirements. For example, novel capture probes such as peptide nucleic acid analogs and microengineered-electrodes-based electrochemical sensors have been designed to avoid cross-hybridization and increase the hybridization efficiency of RNAs where P19 protein was particularly 
employed to remove nonspecific targets. ${ }^{[43,161]}$ Moreover, a simplified electrochemical sensor using direct interaction of target RNA and gold electrode has also been developed to circumvent the multisteps sensor fabrication steps. ${ }^{[41]}$ We have also observed the recent trends of using novel nanomaterials to accelerate the signal transduction and obtain amplified and sensitive detection signal. ${ }^{[182]}$ Despite the rapid advances in the biosensing of mRNAs and circulating miRNAs, development of electrochemical sensor for lncRNAs detection is still in its infancy. Considering their huge clinical potentials, more attention needs to be given to develop an effective and reliable biosensor for lncRNAs. We believe that the ultimate requirement for transforming the current approaches to point-of-care platform is the development of fully automated and integrated biosensors capable of high-throughput screening of RNA biomarkers in a heterogeneous clinical sample. As highly efficient RNA biosensors have continued to develop, we foresee that an ideal RNA biosensor with desired clinical applications will be developed in near future.

\section{Acknowledgements}

This work was supported by the NHMRC CDF (APP1088966 to M.J.A.S.), higher degree research scholarships (GUIPRS and GUPRS scholarships to M.N.I.) from the Griffith University, and a higher degree research scholarship (Matching Scholarship and IPTA award to M.K.M) from University of Wollongong.

\section{Conflict of Interest}

The authors declare no conflict of interest.

\section{Keywords}

detection of RNA, diagnostic and prognostic roles of RNA, electrochemical RNA biosensors, nanotechnology, RNA biomarkers

Received: March 8, 2017

Revised: April 17, 2017

Published online: June 5, 2017

[1] M. Bhat, N. Robichaud, L. Hulea, N. Sonenberg, J. Pelletier I. Topisirovic, Nat. Rev. Drug Discovery 2015, 14, 261.

[2] C. J. David, J. L. Manley, Genes Dev. 2010, 24, 2343.

[3] J. Hayes, P. P. Peruzzi, S. Lawler, Trends Mol. Med. 2014, 20, 460

[4] J. T. Y. Kung, D. Colognori, J. T. Lee, Genetics 2013, 193, 651.

[5] M.-h. Li, S.-b. Fu, H.-s. Xiao, Acta Pharmacol. Sin. 2015, 36, 1200.

[6] J. A. Ludwig, J. N. Weinstein, Nat. Rev. Cancer 2005, 5, 845.

[7] Y. Peng, C. M. Croce, Signal Transduction Targeted Ther. 2016, 1 , 15004.

[8] I. Topisirovic, N. Sonenberg, Cold Spring Harbor Symp. Quant. Biol. 2011, 76, 355.

[9] J. P. Vanden Heuvel, G. C. Clark, C. L. Thompson, Z. McCoy, C. R. Miller, G. W. Lucier, D. A. Bell, Carcinogenesis 1993, 14, 2003.

[10] G. Bertoli, C. Cava, I. Castiglioni, Theranostics 2015, 5, 1122.

[11] T. A. Cooper, L. Wan, G. Dreyfuss, Cell 2009, 136, 777.

[12] C. H. Li, Y. Chen, Int. J. Biochem. Cell Biol. 2013, 45, 1895.
[13] E. Saus, A. Brunet-Vega, S. Iraola-Guzmán, C. Pegueroles, T. Gabaldón, C. Pericay, Front. Genet. 2016, 7, 54.

[14] A. M. Schmitt, H. Y. Chang, Cancer Cell 2016, 29, 452.

[15] S. Zadran, F. Remacle, R. D. Levine, Proc. Natl. Acad. Sci. USA 2013, 110, 19160.

[16] V. Garcia, J. M. Garcia, C. Pena, J. Silva, G. Dominguez, Y. Lorenzo, R. Diaz, P. Espinosa, J. G. de Sola, B. Cantos, F. Bonilla, Cancer Lett. 2008, 263, 312.

[17] N. Miura, H. Nakamura, R. Sato, T. Tsukamoto, T. Harada, S. Takahashi, Y. Adachi, K. Shomori, A. Sano, Y. Kishimoto, H. Ito, J. Hasegawa, G. Shiota, Cancer Sci. 2006, 97, 1366.

[18] M. S. Kopreski, F. A. Benko, L. W. Kwak, C. D. Gocke, Clin. Cancer Res. 1999, 5, 1961.

[19] N. Miura, G. Shiota, T. Nakagawa, Y. Maeda, A. Sano, A. Marumoto, Y. Kishimoto, Y. Murawaki, J. Hasegawa, Oncology 2003, 64, 430 .

[20] A. E. Guttmacher, F. S. Collins, N. Eng. J. Med. 2002, 347, 1512.

[21] S. Oltean, D. O. Bates, Oncogene 2014, 33, 5311.

[22] T. W. Nilsen, B. R. Graveley, Nature 2010, 463, 457.

[23] I. Cascino, G. Fiucci, G. Papoff, G. Ruberti, J. Immunol. 1995, 154, 2706.

[24] M. U. Kaikkonen, M. T. Y. Lam, C. K. Glass, Cardiovasc. Res. 2011, $90,430$.

[25] P. Qi, X. Du, Mod. Pathol. 2013, 26, 155

[26] J. S. Mattick, Bioessays 2010, 32, 548

[27] A. Saxena, P. Carninci, Bioessays 2011, 33, 830.

[28] P. Ji, S. Diederichs, W. Wang, S. Boing, R. Metzger, P. M. Schneider, N. Tidow, B. Brandt, H. Buerger, E. Bulk, M. Thomas, W. E. Berdel, H. Serve, C. Muller-Tidow, Oncogene 2003, 22, 8031.

[29] J. H. Luo, B. Ren, S. Keryanov, G. C. Tseng, U. N. Rao, S. P. Monga, S. Strom, A. J. Demetris, M. Nalesnik, Y. P. Yu, S. Ranganathan, G. K. Michalopoulos, Hepatology 2006, 44, 1012.

[30] K. Yamada, J. Kano, H. Tsunoda, H. Yoshikawa, C. Okubo, T. Ishiyama, M. Noguchi, Cancer Sci. 2006, 97, 106.

[31] M. del Mar Lleò, S. Pierobon, M. C. Tafi, C. Signoretto, P. Canepari, Appl. Environ. Microbiol. 2000, 66, 4564.

[32] I. I. Vandenbroucke, J. Vandesompele, A. D. Paepe, L. Messiaen, Nucleic Acids Res. 2001, 29, e68.

[33] S. H. Lund, D. F. Gudbjartsson, T. Rafnar, A. Sigurdsson, S. A. Gudjonsson, J. Gudmundsson, K. Stefansson, G. Stefansson, PLoS One 2014, 9, e99899.

[34] K. Srinivasan, L. Shiue, J. D. Hayes, R. Centers, S. Fitzwater R. Loewen, L. R. Edmondson, J. Bryant, M. Smith, C. Rommelfanger, V. Welch, T. A. Clark, C. W. Sugnet, K. J. Howe, Y. Mandel-Gutfreund, M. Ares Jr., Methods 2005, 37, 345.

[35] U. M. Ayturk, C. M. Jacobsen, D. C. Christodoulou, J. Gorham, J. G. Seidman, C. E. Seidman, A. G. Robling, M. L. Warman, J. Bone Miner. Res. 2013, 28, 2081.

[36] M. Haider, T. Haselgrubler, A. Sonnleitner, F. Aberger, J. Hesse, Microarrays 2016, 5.

[37] R. Tavallaie, S. R. M. De Almeida, J. J. Gooding, Wiley Interdiscip. Rev.: Nanomed. Nanobiotechnol. 2015, 7, 580.

[38] L. G. Carrascosa, S. Gomez-Montes, A. Avino, A. Nadal, M. Pla R. Eritja, L. M. Lechuga, Nucleic Acids Res. 2012, 40, e56.

[39] L. G. Carrascosa, C. S. Huertas, L. M. Lechuga, TrAC, Trends Anal. Chem. 2016, 80, 177.

[40] C. Pöhlmann, M. Sprinzl, in RNA and DNA Diagnostics (Eds: V. A. Erdmann, S. Jurga, J. Barciszewski), Springer International Publishing, Cham, Switzerland, 2015, pp. 21-45.

[41] K. M. Koo, L. G. Carrascosa, M. J. Shiddiky, M. Trau, Anal. Chem. 2016, 88, 6781 .

[42] S. A. Swanger, G. J. Bassell, C. Gross, Methods Mol. Biol. 2011 $714,103$.

[43] M. Labib, N. Khan, S. M. Ghobadloo, J. Cheng, J. P. Pezacki, M. V. Berezovski, J. Am. Chem. Soc. 2013, 135, 3027. 
[44] M. Labib, E. H. Sargent, S. O. Kelley, Chem. Rev. 2016, 116, 9001.

[45] C. N. Cole, Nat. Genet. 2001, 29, 6.

[46] S. Hahn, Nat. Struct. Mol. Biol. 2004, 119, 394.

[47] N. L. Garneau, J. Wilusz, C. J. Wilusz, Nat. Rev. Mol. Cell Biol. 2007, 8, 113.

[48] N. A. Woychik, M. Hampsey, Cell 2002, 108, 453.

[49] N. Yudkovsky, J. A. Ranish, S. Hahn, Nature 2000, 408, 225.

[50] T. Glisovic, J. L. Bachorik, J. Yong, G. Dreyfuss, FEBS Lett. 2008, 582, 1977.

[51] T. R. Mercer, J. S. Mattick, Nat. Struct. Mol. Biol. 2013, 20, 300.

[52] D. P. Bartel, Cell 2004, 116, 281

[53] M. Guttman, I. Amit, M. Garber, C. French, M. F. Lin, D. Feldser, M. Huarte, O. Zuk, B. W. Carey, J. P. Cassady, M. N. Cabili, R. Jaenisch, T. S. Mikkelsen, T. Jacks, N. Hacohen, B. E. Bernstein, M. Kellis, A. Regev, J. L. Rinn, E. S. Lander, Nature 2009, 458, 223.

[54] G. Dieci, G. Fiorino, M. Castelnuovo, M. Teichmann, A. Pagano, Trends Genet. 2007, 23, 614.

[55] F. Matin, V. Jeet, J. A. Clements, G. M. Yousef, J. Batra, Clin. Chem. 2016, 62, 1318 .

[56] M. Zhou, L. Zhong, W. Xu, Y. Sun, Z. Zhang, H. Zhao, L. Yang, J. Sun, Sci. Rep. 2016, 6, 31038.

[57] T. Kishikawa, M. Otsuka, M. Ohno, T. Yoshikawa, A. Takata, K. Koike, World J. Gastroenterol. 2015, 21, 8527.

[58] H. Peng, J. Wang, J. Li, M. Zhao, S.-k. Huang, Y.-y. Gu, Y. Li, X.-j. Sun, L. Yang, Q. Luo, C.-z. Huang, Life Sci. 2016, 151, 235.

[59] S. A. Tomlins, B. Laxman, S. Varambally, X. Cao, J. Yu, B. E. Helgeson, Q. Cao, J. R. Prensner, M. A. Rubin, R. B. Shah, R. Mehra, A. M. Chinnaiyan, Neoplasia 2008, 10, 177

[60] P. Qi, X.-y. Zhou, X. Du, Mol. Cancer 2016, 15, 39.

[61] M. K. Pal, S. P. Jaiswar, V. N. Dwivedi, A. K. Tripathi, A. Dwivedi, P. Sankhwar, Cancer Biol. Med. 2015, 12, 328.

[62] F. Bettazzi, E. Hamid-Asl, C. L. Esposito, C. Quintavalle, N. Formisano, S. Laschi, S. Catuogno, M. Iaboni, G. Marrazza, M. Mascini, L. Cerchia, V. De Franciscis, G. Condorelli, I. Palchetti, Anal. Bioanal. Chem. 2013, 405, 1025.

[63] J. D. Arroyo, J. R. Chevillet, E. M. Kroh, I. K. Ruf, C. C. Pritchard, D. F. Gibson, P. S. Mitchell, C. F. Bennett, E. L. Pogosova-Agadjanyan, D. L. Stirewalt, J. F. Tait, M. Tewari, Proc. Natl. Acad. Sci. USA 2011, 108, 5003.

[64] X. Chen, Y. Ba, L. Ma, X. Cai, Y. Yin, K. Wang, J. Guo, Y. Zhang, J. Chen, X. Guo, Q. Li, X. Li, W. Wang, Y. Zhang, J. Wang, X. Jiang, Y. Xiang, C. Xu, P. Zheng, J. Zhang, R. Li, H. Zhang, X. Shang, T. Gong, G. Ning, J. Wang, K. Zen, J. Zhang, C. Y. Zhang, Cell Res. 2008, 18, 997.

[65] G. Rabinowits, C. Gercel-Taylor, J. M. Day, D. D. Taylor, G. H. Kloecker, Clin. Lung Cancer 2009, 10, 42.

[66] S. Ono, S. Lam, M. Nagahara, D. Hoon, J. Clin. Med. 2015, 4, 1890.

[67] M. Fernandez-Mercado, L. Manterola, E. Larrea, I. Goicoechea, M. Arestin, M. Armesto, D. Otaegui, C. H. Lawrie, J. Cell. Mol. Med. 2015, 19, 2307.

[68] W.-T. Wang, Y.-M. Sun, W. Huang, B. He, Y.-N. Zhao, Y.-Q. Chen, Sci. Rep. 2016, 6, 23343

[69] J. A. Weber, D. H. Baxter, S. Zhang, D. Y. Huang, K. How Huang, M. Jen Lee, D. J. Galas, K. Wang, Clin. Chem. 2010, 56, 1733.

[70] K. R. Chi, Nature 2016, 532, 269.

[71] S. Debernardi, N. J. Massat, T. P. Radon, A. Sangaralingam, A. Banissi, D. P. Ennis, T. Dowe, C. Chelala, S. P. Pereira, H. M. Kocher, B. D. Young, G. Bond-Smith, R. Hutchins, T. Crnogorac-Jurcevic, Am. J. Cancer Res. 2015, 5, 3455.

[72] J. Kupryjanczyk, T. Szymanska, R. Madry, A. Timorek, J. Stelmachow, G. Karpinska, A. Rembiszewska, I. Ziolkowska, E. Kraszewska, J. Debniak, J. Emerich, M. Ulanska, A. Pluzanska, M. Jedryka, M. Goluda, A. Chudecka-Glaz, I. Rzepka-Gorska, M. Klimek, K. Urbanski, J. Breborowicz, J. Zielinski, J. Markowska, Br. J. Cancer 2003, 88, 848 .
[73] T. Hou, C. Yang, C. Tong, H. Zhang, J. Xiao, J. Li, Int. J. Clin. Exp. Pathol. 2014, 7, 280.

[74] D. Sinicropi, K. Qu, F. Collin, M. Crager, M.-L. Liu, R. J. Pelham, M. Pho, A. D. Rossi, J. Jeong, A. Scott, R. Ambannavar, C. Zheng, R. Mena, J. Esteban, J. Stephans, J. Morlan, J. Baker, PLoS One 2012, 7, e40092.

[75] A. Lapuk, H. Marr, L. Jakkula, H. Pedro, S. Bhattacharya, E. Purdom, Z. Hu, K. Simpson, L. Pachter, S. Durinck, N. Wang, B. Parvin, G. Fontenay, T. Speed, J. Garbe, M. Stampfer, H. Bayandorian, S. Dorton, T. A. Clark, A. Schweitzer, A. Wyrobek, H. Feiler, P. Spellman, J. Conboy, J. W. Gray, Mol. Cancer Res. 2010, $8,961$.

[76] F. J. de Miguel, R. D. Sharma, M. J. Pajares, L. M. Montuenga, A. Rubio, R. Pio, Cancer Res. 2014, 74, 1105.

[77] R. Ren, Nat. Rev. Cancer 2005, 5, 172.

[78] K. Kang, X. Peng, J. Luo, D. Gou, J. Anim. Sci. Biotechnol. 2012, 3, 4.

[79] G. A. Calin, C. D. Dumitru, M. Shimizu, R. Bichi, S. Zupo, E. Noch, H. Aldler, S. Rattan, M. Keating, K. Rai, L. Rassenti, T. Kipps, M. Negrini, F. Bullrich, C. M. Croce, Proc. Natl. Acad. Sci. USA 2002, 99, 15524.

[80] S. Volinia, G. A. Calin, C. G. Liu, S. Ambs, A. Cimmino, F. Petrocca, R. Visone, M. Iorio, C. Roldo, M. Ferracin, R. L. Prueitt, N. Yanaihara, G. Lanza, A. Scarpa, A. Vecchione, M. Negrini, C. C. Harris, C. M. Croce, Proc. Natl. Acad. Sci. USA 2006, 103, 2257.

[81] C. H. Lawrie, S. Gal, H. M. Dunlop, B. Pushkaran, A. P. Liggins, K. Pulford, A. H. Banham, F. Pezzella, J. Boultwood, J. S. Wainscoat, C. S. Hatton, A. L. Harris, Br. J. Haematol. 2008, 141, 672.

[82] J. Zhou, L. Yu, X. Gao, J. Hu, J. Wang, Z. Dai, J. F. Wang, Z. Zhang, S. Lu, X. Huang, Z. Wang, S. Qiu, X. Wang, G. Yang, H. Sun, Z. Tang, Y. Wu, H. Zhu, J. Fan, J. Clin. Oncol. 2011, 29, 4781.

[83] S. W. Cheetham, F. Gruhl, J. S. Mattick, M. E. Dinger, Br. J. Cancer 2013, 108, 2419

[84] R. A. Gupta, N. Shah, K. C. Wang, J. Kim, H. M. Horlings, D. J. Wong, M. C. Tsai, T. Hung, P. Argani, J. L. Rinn, Y. Wang, P. Brzoska, B. Kong, R. Li, R. B. West, M. J. van de Vijver, S. Sukumar, H. Y. Chang, Nature 2010, 464, 1071.

[85] D. Spentzos, D. A. Levine, M. F. Ramoni, M. Joseph, X. Gu, J. Boyd, T. A. Libermann, S. A. Cannistra, J. Clin. Oncol. 2004, 22, 4700.

[86] E. M. F. De Sousa, X. Wang, M. Jansen, E. Fessler, A. Trinh, L. P. de Rooij, J. H. de Jong, O. J. de Boer, R. van Leersum, M. F. Bijlsma, H. Rodermond, M. van der Heijden, C. J. van Noesel, J. B. Tuynman, E. Dekker, F. Markowetz, J. P. Medema, L. Vermeulen, Nat. Med. 2013, 19, 614.

[87] R. Kridel, B. Meissner, S. Rogic, M. Boyle, A. Telenius, B. Woolcock, J. Gunawardana, C. Jenkins, C. Cochrane, S. Ben-Neriah, K. Tan, R. D. Morin, S. Opat, L. H. Sehn, J. M. Connors, M. A. Marra, A. P. Weng, C. Steidl, R. D. Gascoyne, Blood 2012, 119, 1963.

[88] J. Lu, G. Getz, E. A. Miska, E. Alvarez-Saavedra, J. Lamb, D. Peck, A. Sweet-Cordero, B. L. Ebert, R. H. Mak, A. A. Ferrando, J. R. Downing, T. Jacks, H. R. Horvitz, T. R. Golub, Nature 2005, $435,834$.

[89] A. J. Schetter, S. Y. Leung, J. J. Sohn, K. A. Zanetti, E. D. Bowman, N. Yanaihara, S. T. Yuen, T. L. Chan, D. L. Kwong, G. K. Au, C. G. Liu, G. A. Calin, C. M. Croce, C. C. Harris, JAMA 2008, 299, 425.

[90] R. Kogo, T. Shimamura, K. Mimori, K. Kawahara, S. Imoto, T. Sudo, F. Tanaka, K. Shibata, A. Suzuki, S. Komune, S. Miyano, M. Mori, Cancer Res. 2011, 71, 6320.

[91] J. Takamizawa, H. Konishi, K. Yanagisawa, S. Tomida, H. Osada, H. Endoh, T. Harano, Y. Yatabe, M. Nagino, Y. Nimura, T. Mitsudomi, T. Takahashi, Cancer Res. 2004, 64, 3753. 
[92] S. F. Tavazoie, C. Alarcon, T. Oskarsson, D. Padua, Q. Wang, P. D. Bos, W. L. Gerald, J. Massague, Nature 2008, 451, 147.

[93] Y. Liu, M. Zhang, L. Liang, J. Li, Y. X. Chen, Int. J. Clin. Exp. Pathol. $2015,8,11480$.

[94] Y. Yatabe, R. Suzuki, K. Tobinai, Y. Matsuno, R. Ichinohasama, M. Okamoto, M. Yamaguchi, J. Tamaru, N. Uike, Y. Hashimoto, Y. Morishima, T. Suchi, M. Seto, S. Nakamura, Blood 2000, 95, 2253.

[95] A. Schaefer, M. Jung, H. J. Mollenkopf, I. Wagner, C. Stephan, F. Jentzmik, K. Miller, M. Lein, G. Kristiansen, K. Jung, Int. J. Cancer 2010, 126, 1166

[96] A. Srivastava, H. Goldberger, A. Dimtchev, M. Ramalinga, J. Chijioke, C. Marian, E. K. Oermann, S. Uhm, J. S. Kim, L. N. Chen, X. Li, D. L. Berry, B. V. S. Kallakury, S. C. Chauhan, S. P. Collins, S. Suy, D. Kumar, PLoS One 2013, 8, e76994.

[97] W. Wang, X. He, Z. Zheng, X. Ma, X. Hu, D. Wu, M. Wang, Mol. Cancer 2017, 16, 75.

[98] B. A. Haider, A. S. Baras, M. N. McCall, J. A. Hertel, T. C. Cornish, M. K. Halushka, PLoS One 2014, 9, e89565.

[99] K. W. Witwer, Clin. Chem. 2015, 61, 56.

[100] M. G. Egidi, G. Cochetti, M. R. Serva, G. Guelfi, D. Zampini, L. Mechelli, E. Mearini, Biomed. Res. Int. 2013, 241780.

[101] R. Singh, B. Ramasubramanian, S. Kanji, A. R. Chakraborty, S. J. Haque, A. Chakravarti, Cancer Lett. 2016, 381, 113.

[102] A. Kappel, A. Keller, Clin. Chem. Lab. Med. 2017, 55, 636.

[103] R. S. Leidner, L. Li, C. L. Thompson, PLoS One 2013, 8, e57841.

[104] L. Moldovan, K. E. Batte, J. Trgovcich, J. Wisler, C. B. Marsh, M. Piper, J. Cell. Mol. Med. 2014, 18, 371.

[105] A. K. Watson, K. W. Witwer, Clin. Chem. 2012, 58, 472

[106] A. P. Frei, F.-A. Bava, E. R. Zunder, E. W. Y. Hsieh, S.-Y. Chen, G. P. Nolan, P. F. Gherardini, Nat. Methods 2016, 13, 269.

[107] K. Wang, Y. Yuan, J.-H. Cho, S. McClarty, D. Baxter, D. J. Galas, PLoS One 2012, 7, e41561.

[108] P. Leidinger, C. Backes, S. Rheinheimer, A. Keller, E. Meese, PLoS One 2015, 10, e0143321.

[109] J. S. McDonald, D. Milosevic, H. V. Reddi, S. K. Grebe, A. Algeciras-Schimnich, Clin. Chem. 2011, 57, 833.

[110] Z. Dvorak, J. M. Pascussi, M. Modriansky, Biomed. Pap. 2003, 147, 131.

[111] M. Castoldi, S. Schmidt, V. Benes, M. Noerholm, A. E. Kulozik, M. W. Hentze, M. U. Muckenthaler, RNA 2006, 12, 913.

[112] M. V. Riquelme, H. Zhao, V. Srinivasaraghavan, A. Pruden, P. Vikesland, M. Agah, Sens. Bio-Sens. Res. 2016, 8, 47.

[113] R. Shi, V. L. Chiang, Biotechniques 2005, 39, 519.

[114] C. Chen, D. A. Ridzon, A. J. Broomer, Z. Zhou, D. H. Lee, J. T. Nguyen, M. Barbisin, N. L. Xu, V. R. Mahuvakar, M. R. Andersen, K. Q. Lao, K. J. Livak, K. J. Guegler, Nucleic Acids Res. 2005, 33, e179.

[115] Y. Wan, M. Kertesz, R. C. Spitale, E. Segal, H. Y. Chang, Nat. Rev. Genet. 2011, 12, 641.

[116] R. Li, H. Zhu, Y. Luo, Int. J. Mol. Sci. 2016, 17, 702.

[117] S. A. Bustin, J. Mol. Endocrinol. 2002, 29, 23.

[118] F. Ozsolak, P. M. Milos, Nat. Rev. Genet. 2011, 12, 87.

[119] E. M. Kroh, R. K. Parkin, P. S. Mitchell, M. Tewari, Methods 2010, 50, 298.

[120] P. Mestdagh, N. Hartmann, L. Baeriswyl, D. Andreasen, N. Bernard, C. Chen, D. Cheo, P. D'Andrade, M. DeMayo, L. Dennis, S. Derveaux, Y. Feng, S. Fulmer-Smentek, B. Gerstmayer, I. Gouffon, C. Grimley, E. Lader, K. Y. Lee, S. Luo, P. Mouritzen, A. Narayanan, S. Patel, S. Peiffer, S. Ruberg, G. Schroth, D. Schuster, J. M. Shaffer, E. J. Shelton, S. Silveria, U. Ulmanella, V. Veeramachaneni, F. Staedtler, T. Peters, T. Guettouche, L. Wong, J. Vandesompele, Nat. Methods 2014, 11, 809.

[121] E. Marshall, Science 2004, 306, 630.

[122] H. M. Fathallah-Shaykh, Arch. Neurol. 20058, 62, 1669.
[123] A. Butte, Nat. Rev. Drug Discovery 2002, 1, 951.

[124] Y. Shi, J. Shang, Microarrays Methods Mol. Biol. 2016, 1402, 43.

[125] H. Zhu, Q. Wang, Y. Yao, J. Fang, F. Sun, Y. Ni, Y. Shen, H. Wang, S. Shao, BMC Med. Genomics 2015, 8, 84

[126] C. E. Rogler, T. Tchaikovskaya, R. Norel, A. Massimi, C. Plescia, E. Rubashevsky, P. Siebert, L. E. Rogler, Nucleic Acids Res. 2004, 32, e120.

[127] Y. Hu, X. Qin, D. Yan, H. Cao, L. Zhou, F. Fan, J. Zang, J. Ni, X. Xu, H. Sha, S. Liu, S. Yu, J. Wu, R. Ma, J. Feng, Tumor Biol. 2017, 39, DOI: $10.1177 / 1010428317691659$.

[128] T. Li, J. Xie, C. Shen, D. Cheng, Y. Shi, Z. Wu, X. Deng, H. Chen, B. Shen, C. Peng, H. Li, Q. Zhan, Z. Zhu, Oncogene 2016, 35 1575

[129] Q. Rui, Z. Xu, P. Yang, Z. He, Biomed. Pharmacother. 2015, 75, 12.

[130] L.-z. Meng, J.-g. Fang, J.-w. Sun, F. Yang, Y.-x. Wei, Biomed Res. Int. 2016, 1095710.

[131] L. Yan, J. Zhou, Y. Zheng, A. S. Gamson, B. T. Roembke, S. Nakayama, H. O. Sintim, Mol. Biosyst. 2014, 10, 970.

[132] D. Horibe, T. Ochiai, H. Shimada, T. Tomonaga, F. Nomura, M. Gun, T. Tanizawa, H. Hayashi, Int. J. Cancer 2007, 120, 1063.

[133] T. Notomi, H. Okayama, H. Masubuchi, T. Yonekawa, K. Watanabe, N. Amino, T. Hase, Nucleic Acids Res. 2000, 28, e63.

[134] D.-C. Nyan, K. L. Swinson, Int. J. Infect. Dis. 2016, 43, 30.

[135] T. Kobori, H. Takahashi, Anal. Sci. 2014, 30, 59.

[136] T. Murakami, J. Sumaoka, M. Komiyama, Nucleic Acids Res. 2012, 40, e22.

[137] S. D. Wharam, P. Marsh, J. S. Lloyd, T. D. D. Ray, G. A. Mock, R. Assenberg, J. E. McPhee, P. Brown, A. Weston, D. L. N. Cardy, Nucleic Acids Res. 2001, 29, e54.

[138] G. J. Nuovo, Diagn. Mol. Pathol. 2000, 9, 195.

[139] H. Fujita, Y. Kataoka, S. Tobita, M. Kuwahara, N. Sugimoto, Anal. Chem. 2016, 88, 7137

[140] M. N. Islam, S. Yadav, M. H. Haque, A. Munaz, F. Islam, M. S. Al Hossain, V. Gopalan, A. K. Lam, N.-T. Nguyen, M. J. A. Shiddiky, Biosens. Bioelectron. 2017, 92, 668.

[141] H. Sipova, S. Zhang, A. M. Dudley, D. Galas, K. Wang, J. Homola, Anal. Chem. 2010, 82, 10110.

[142] C. S. Huertas, L. G. Carrascosa, S. Bonnal, J. Valcárcel, L. M. Lechuga, Biosens. Bioelectron. 2016, 78, 118

[143] H.-N. Wang, B. M. Crawford, A. M. Fales, M. L. Bowie, V. L. Seewaldt, T. Vo-Dinh, J. Phys. Chem. C 2016, 120, 21047.

[144] J. D. Driskell, A. G. Seto, L. P. Jones, S. Jokela, R. A. Dluhy, Y. P. Zhao, R. A. Tripp, Biosens. Bioelectron. 2008, 24, 923.

[145] K. M. Koo, E. J. H. Wee, P. N. Mainwaring, Y. Wang, M. Trau, Small 2016, 12, 6233.

[146] D. S. Seferos, D. A. Giljohann, H. D. Hill, A. E. Prigodich, C. A. Mirkin, J. Am. Chem. Soc. 2007, 129, 15477.

[147] J. B. Opalinska, A. M. Gewirtz, Nat. Rev. Drug Discovery 2002, 1 , 503.

[148] A. E. Prigodich, D. S. Seferos, M. D. Massich, D. A. Giljohann, B. C. Lane, C. A. Mirkin, ACS Nano 2009, 3, 2147.

[149] W. E. Briley, M. H. Bondy, P. S. Randeria, T. J. Dupper, C. A. Mirkin, Proc. Natl. Acad. Sci. USA 2015, 112, 9591.

[150] F. Olasagasti, K. R. Lieberman, S. Benner, G. M. Cherf, J. M. Dahl, D. W. Deamer, M. Akeson, Nat. Nanotehnol. 2010, 5, 798.

[151] J. Clarke, H.-C. Wu, L. Jayasinghe, A. Patel, S. Reid, H. Bayley, Nat. Nanotehnol. 2009, 4, 265

[152] R. Y. Henley, S. Carson, M. Wanunu, Prog. Mol. Biol. Transl. Sci. 2016, 139, 73

[153] L.-Q. Gu, M. Wanunu, M. X. Wang, L. McReynolds, Y. Wang, Expert Rev. Mol. Diagn. 2012, 12, 573.

[154] M. Wanunu, T. Dadosh, V. Ray, J. Jin, L. McReynolds, M. Drndic, Nat. Nanotehnol. 2010, 5, 807.

[155] Y. Wang, D. Zheng, Q. Tan, M. X. Wang, L.-Q. Gu, Nat. Nanotehnol. 2011, 6, 668. 
[156] C. C. Pritchard, H. H. Cheng, M. Tewari, Nat. Rev. Genet. 2012, 13, 358.

[157] D. Gustafson, K. Tyryshkin, N. Renwick, J. Clin. Endocrinol. Metab. 2016, 30, 563.

[158] S. Fang, H. J. Lee, A. W. Wark, R. M. Corn, J. Am. Chem. Soc. 2006, $128,14044$.

[159] H. Xie, Y. H. Yu, F. Xie, Y. Z. Lao, Z. Gao, Anal. Chem. 2004, 76, 4023.

[160] F. Wei, J. Wang, W. Liao, B. G. Zimmermann, D. T. Wong, C.-M. Ho, Nucleic Acids Res. 2008, 36, e65.

[161] E. Vasilyeva, B. Lam, Z. Fang, M. D. Minden, E. H. Sargent, S. O. Kelley, Angew. Chem., Int. Ed. 2011, 50, 4137.

[162] M. R. Hartman, R. C. H. Ruiz, S. Hamada, C. Xu, K. G. Yancey, Y. Yu, W. Han, D. Luo, Nanoscale 2013, 5, 10141.

[163] B. N. Johnson, R. Mutharasan, Analyst 2014, 139, 1576.

[164] H. Yang, A. Hui, G. Pampalakis, L. Soleymani, F.-F. Liu, E. H. Sargent, S. O. Kelley, Angew. Chem., Int. Ed. 2009, 48, 8461.

[165] Z. Fang, L. Soleymani, G. Pampalakis, M. Yoshimoto, J. A. Squire, E. H. Sargent, S. O. Kelley, ACS Nano 2009, 3, 3207.

[166] R. M. Mohamadi, I. Ivanov, J. Stojcic, R. K. Nam, E. H. Sargent, S. O. Kelley, Anal. Chem. 2015, 87, 6258.

[167] F. Wei, P. Patel, W. Liao, K. Chaudhry, L. Zhang, M. Arellano-Garcia, S. Hu, D. Elashoff, H. Zhou, S. Shukla, F. Shah, C. M. Ho, D. T. Wong, Clin. Cancer Res. 2009, 15, 4446.

[168] X. Chen, S. Roy, Y. Peng, Z. Gao, Anal. Chem. 2010, 82, 5958.

[169] J. Liu, H. Zhou, J.-J. Xu, H.-Y. Chen, Analyst 2012, 137, 3940.
[170] F. Mertens, B. Johansson, T. Fioretos, F. Mitelman, Nat. Rev. Cancer 2015, 15, 371

[171] J. Liu, L. Weng, Y. Ming, B. Yin, S. Liu, N. Wu, Z. Wu, Diagn. Pathol. Open 2016, 1, 108

[172] F. Mitelman, B. Johansson, F. Mertens, Nat. Rev. Cancer 2007, 7, 233.

[173] G. Attard, C. Parker, R. A. Eeles, F. Schroder, S. A. Tomlins, I. Tannock, C. G. Drake, J. S. de Bono, Lancet 2016, 387, 70.

[174] K. M. Koo, A. A. I. Sina, L. G. Carrascosa, M. J. A. Shiddiky, M. Trau, Anal. Methods 2015, 7, 7042.

[175] J. Supper, C. Gugenmus, J. Wollnik, T. Drueke, M. Scherf, A. Hahn, K. Grote, N. Bretschneider, B. Klocke, C. Zinser, K. Cartharius, M. Seifert, Methods 2013, 59, S24.

[176] S. Kumar, A. D. Vo, F. Qin, H. Li, Sci. Rep. 2016, 6, 21597.

[177] E. A. Lusi, M. Passamano, P. Guarascio, A. Scarpa, L. Schiavo, Anal. Chem. 2009, 81, 2819.

[178] C.-Y. Hong, X. Chen, T. Liu, J. Li, H.-H. Yang, J.-H. Chen, G.-N. Chen, Biosens. Bioelectron. 2013, 50, 132.

[179] N. Khan, J. Cheng, J. P. Pezacki, M. V. Berezovski, Anal. Chem. 2011, 83, 6196

[180] T. Kilic, S. Nur Topkaya, M. Ozsoz, Biosens. Bioelectron. 2013, 48, 165

[181] F. Liu, G. Xiang, D. Jiang, L. Zhang, X. Chen, L. Liu, F. Luo, Y. Li, C. Liu, X. Pu, Biosens. Bioelectron. 2015, 74, 214.

[182] F. Liu, G. Xiang, L. Zhang, D. Jiang, L. Liu, Y. Li, C. Liu, X. Pu, RSC Adv. 2015, 5, 51990. 